\title{
Tax-Deferred Savings and Early Retirement
}

\author{
Gaobo Pang* \\ University of Maryland
}

First Draft - July, 2005

This Version - May, 2006

\begin{abstract}
This paper analyzes effects of tax-favored savings plans on savings and retirement decisions in a realistically specified life-cycle model. Individuals face mortality risk and stochastic earnings, allocate assets between conventional savings accounts (CSAs) and tax-deferred accounts (TDAs), make endogenous choice of labor supply and retirement, and make a separate decision on claiming Social Security. The simulations reveal that there is a functional division to some degree between CSAs and TDAs, with the former serving mainly for liquidity and the latter for retirement and bequests. There is tremendous heterogeneity. The tax incentives are generally effective in stimulating new savings for the middle and upper income groups. The higher rate of return on TDAs facilitates wealth accumulation, which consequently and perhaps unintentionally encourages early retirement. Impatient and low-income individuals tend to retire and claim Social Security early. They derive less benefit from TDAs since they face lower marginal tax rates and they have limited resources to take advantage of TDAs. For them, the income effect dominates and TDAs fail to induce new savings.
\end{abstract}

${ }^{*}$ Correspondence to pang@econ.umd.edu. Department of Economics, 3105 Tydings Hall, University of Maryland, College Park, MD 20742. I am very grateful to John Rust, John Shea, Mark Duggan, Michael Pries, Bill Evans, Jonah Gelbach, and Joe Nichols for their helpful comments and suggestions. Workshop participants at the University of Maryland and CEANA annual conference are acknowledged for their valuable contributions. I would like to thank John Rust and Joe Nichols for their help on computational issues. All errors are my sole responsibility. 


\section{Introduction}

This paper explores the impact of tax deferred accounts (TDAs) on early retirement decisions and the implication of planned early retirement for the effectiveness of tax incentives at stimulating new savings.

Tax deferred accounts, particularly IRAs and 401(k)s introduced in early 1980s, were intended to stimulate private savings to support retirement and economic growth in the long run. They rapidly became popular. TDA contributions by 1986 exceeded contributions to traditional defined benefit (DB) and defined contribution (DC) plans (Poterba, Venti and Wise (1996)) and have accounted for one-third of private savings ever since (Engen, Gale and Scholz (1994)). ${ }^{1}$ Tax deferred programs are also costly. For instance, Gravelle (2003) estimated that the revenue loss from IRA universal coverage would be $\$ 66$ billion for 5 years. The debate about the effectiveness of tax incentives embedded in TDAs at inducing new savings forms an active strand of research. Venti and Wise $(1986,1987,1990,1995)$ and Poterba, Venti and Wise (1994, 1995, 1996) view large part of TDA contributions as new savings; Engen and Gale (1993) and Engen, Gale and Scholz $(1994,1996)$ find limited evidence for new savings; Hubbard and Skinner (1996) judge the effectiveness of saving incentives to be somewhere in between; and Benjamin (2003) recently estimates that one half of 401(k) balances are new private savings. ${ }^{2}$

\footnotetext{
${ }^{1}$ Traditional non-401(k) DC plans are primarily funded by employer contributions. Contributions to $401(\mathrm{k})$ plans are at the saving choices of participants and are often augmented by employer matching.

${ }^{2}$ The assessment of effectiveness should in the first place exclude forced savings by firms replacing DB pension plans with 401(k)s. Poterba, Venti and Wise (2001) document the shift from employer managed DB plans to employee controlled DC plans over the last two decades. They point out
} 
The effectiveness of tax incentives depends critically on whether TDAs have inspired new savings. The literature shows that personal savings are largely driven by three motives: for liquidity (including precautionary and transaction needs), for retirement preparation and for bequests. Precautionary savings arise when households face uncertainty over earnings, medical expenses or other shocks and face borrowing limits in a world of incomplete markets for lending and insurance. Retirement savings are for life-cycle reasons in order to support consumption absent new flows of labor income. While these factors can explain the lower tail of the wealth distribution, researchers have found that the bequest motive plays an important role in generating wealth-income patterns consistent with the upper tail of wealth. ${ }^{3}$ These motives matter when individuals choose the vehicles for savings. Deposits in TDAs are income tax deductible, returns accrue tax-free, and taxes are paid upon withdrawal. This tax structure makes TDAs attractive for long term saving since they provide savers with a higher return than conventional savings (CSAs). In the meantime, the early withdrawal penalty makes TDAs a quite costly source for liquidity financing. It thus makes much sense to make a functional division, allocating savings for liquidity into CSAs and retirement and bequest savings into TDAs.

The existing literature on the effectiveness of tax incentives has incorporated these saving motives to some extent, but has not yet captured the complex interactions that "the micro data show no evidence that the accumulation of 401(k) assets has been offset by a reduction in defined benefit assets." This implies that the popularity of TDAs is largely the choice at employees' discretion.

\footnotetext{
${ }^{3}$ See, among others, Kotlikoff and Summers (1981), Hurd and Smith (1999), Dynan, Skinner and Zeldes (1996), and De Nardi (2004).
} 
between simultaneous savings and leisure choices. Previous studies treat retirement as an exogenous and mandatory shift at some specific age, which by assumption rules out a potentially important stimulus to save - the possibility of early retirement. There is good reason to believe that endogenous retirement choice plays an important role in shaping the savings profile. If always employed until an exogenous retirement age, households will boost current consumption as well as gradually accumulating retirement wealth. With endogenous retirement decisions, however, individuals may depress their consumption growth rate and contribute to TDAs more significantly in the preparation for early retirement. In short, the impact of tax incentives on saving is closely associated with leisure choice and varies at different stages of the life cycle. Another related strand of research has examined the relationship between wealth and retirement choice. The literature remains divided. Burtless (1986) shows that the unanticipated Social Security benefit increases in 1969-1973 induced retirement, while Krueger and Pischke (1992) find that the reduction in Social Security wealth did not reverse the decline in labor supply of the "notch" generation. Imbens, Rubin and Sacerdote (2001) find that lottery wealth induces retirement. Gustman and Steinmeier (1986) and Samwick (1998) report a small wealth effect on retirement. Hurd and Reti (2001) find no evidence that large stock market gains induce early retirement. An apparent caveat of previous studies is that they mainly focus on wealth change in after-tax accounts, while the omitted wealth in TDAs is substantial for many households and may constitute an important factor determining retirement. With higher rates of return, TDAs offer a more effective means for long-term asset 
accumulation that may encourage early retirement. However, it is a challenge to empirically identify the wealth effect of TDAs on retirement because of the short exposure to date of retiring cohorts to these tax deferred programs. A structural lifecycle model incorporating TDAs serves as a natural step to tackle the wealth effect on retirement and will shed light on the long-run pattern of labor supply.

This paper incorporates endogenous labor supply (and thus retirement) decisions as well as all of the above saving motives into a realistically specified life-cycle model. Individuals face stochastic earnings in a world of incomplete markets. Realizations of earnings shocks produce income heterogeneity. Differing attitudes toward disutility of work generate preference heterogeneity in leisure and retirement choice. The model captures asset allocations between conventional and tax-deferred savings accounts. The presence of liquidity constraints justifies the need for savings in CSAs. Retirement and bequest motives induce households to make optimal allocations into TDAs.

I also carefully introduce a pay-as-you-go Social Security system, for two important reasons. First, Social Security serves as one of the major financing resources for retirement in practice, especially for those with relatively low income. Second, incorporating Social Security helps to avoid overstating the role of TDAs. Individuals make endogenous choices on when to claim Social Security, which are separate from their retirement decisions. This is another contribution of this paper. Previous studies assuming identical timing of retirement and benefit take-up found that liquidity constrained individuals should retire early to obtain Social Security. My model predicts that high-income individuals may choose to retire earlier than otherwise by 
virtue of effective wealth accumulation through TDAs, claiming Social Security as a complement, even though they are not facing a shortage of income.

The life-cycle model in this paper is similar in spirit to those in Engen and Gale (1993) and Engen, Gale and Scholz (1994). The simulations confirm their findings that TDA and CSA assets are imperfect substitutes when savings are mainly for liquidity purpose due to the early withdrawal penalty on TDAs, and that the substitutability increases with age when savings are mainly for retirement. A step further, I introduce important new elements: an intentional bequest motive, a separate decision on Social Security, and particularly endogenous labor supply and retirement decisions for the reasons outlined above. This comprehensive modeling proves to be fruitful, despite considerable computational cost, and yields illuminating findings. The effectiveness of saving incentives varies with income and preference heterogeneity. Tax deferred programs enhance individual welfare and at the same time encourage early retirement, perhaps unintentionally. Allowing for early retirement induces individuals in the model to accumulate more private savings, but with a larger share of asset reshuffling from CSAs to TDAs.

Several limitations should be noted. First, this model incorporates the public Social Security system, but assumes no private annuity market nor employer-provided DB pension plans, and abstracts from employer-matching of contributions to $401(\mathrm{k}) \mathrm{s}$, the popular DC plans. The literature has postulated private pensions as an important force manipulating individual retirement behavior, as employees frequently must remain with their employer until some specific age to attain pension eligibility. Second, 
housing wealth is not explicitly modeled. For many households, home equity accounts for a large part of their total wealth, which may substantially restrict their utilization of TDAs. Third, the model abstracts from medical costs, employer-provided insurance and Medicare programs. Rust and Phelan (1997), Rust (2005), and Blau and Gilleskie (2003) illustrate that private and public insurance programs have significant employment effects. Fourth, the model assumes a deterministic rate of return on savings and does not address the portfolio choice of bonds and equities in CSAs and TDAs (see Huang (2003), Poterba and Samwick (2003), Shoven and Sialm (2003), and Dammon, Spatt and Zhang (2004) along this line). ${ }^{4}$

The remainder of the paper is organized as follows: Section 2 describes the relationship between investment horizon and asset location choice; Section 3 outlines the life cycle model featuring asset allocations between CSAs and TDAs, endogenous labor/leisure choice, and separate Social Security decisions in an environment of stochastic earnings with a comprehensive tax system; Section 4 provides heuristic findings about consumption, savings and retirement decisions; Section 5 reports the findings from numerical simulations; Section 6 contains experiments for alternative TDA policy scenarios and reports experiments for the cases of partial myopia and the correlation of mortality with income; and Section 7 concludes.

\footnotetext{
${ }^{4}$ The capital gains tax rate for stocks is typically lower than the marginal tax rate for interest and labor income. The benefit from tax deferral is thus lower for saving in stocks in TDAs. Dammon, Spatt and Zhang (2004) show that individuals should hold in priority the heavily taxed bonds in TDAs. To balance risk exposure, individuals may find it optimal to hold both bonds and stocks in TDAs, in which case the recent capital gain tax reduction may weaken the tax advantage of TDAs.
} 


\section{Asset Location and Investment Horizon}

\subsection{Tax-Deferred and Conventional Savings Accounts}

There are two different types of accounts: conventional savings accounts (CSAs) and tax deferred accounts (TDAs). The former refer to saving vehicles whose funds can be utilized freely at the owner's will. The latter refer broadly to special savings programs, including front-loaded plans such as traditional Individual Retirement Accounts (IRAs), 401(k)s, 403(b)s, and supplemental retirement accounts (SRAs), and back-loaded plans such as Roth IRAs. For front-loaded plans, both income taxes on initial contributions and the taxes on interest and capital gains are deferred, and accumulations are taxed as ordinary income only upon withdrawal. For back-loaded plans, initial contributions are subject to ordinary income tax and there are no taxes on future withdrawals. The following example illustrates that Roth IRAs and other TDAs are similar in nature. Let $\tau_{0}$ and $\tau_{1}$ be the current and future income tax rates, respectively. Suppose pre-tax $\$ 1$ is invested in a $401(\mathrm{k})$ and the equivalent after-tax amount $\left(1-\tau_{0}\right) \$ 1$ in a Roth IRA, and suppose the gross return is $R$ at the terminal date. Then the after-tax value for a Roth IRA investment is $\left(1-\tau_{0}\right) R$ while that for a 401(k) investment is $\left(1-\tau_{1}\right) R$. Clearly each dollar in a Roth IRA is equivalent to

$\frac{1-\tau_{0}}{1-\tau_{1}}$ dollars in a $401(\mathrm{k})$. The values are identical under if the tax rate applicable to the individual does not change over time $\left(\tau_{0}=\tau_{1}\right)$, while the $401(\mathrm{k})$ is more beneficial within a progressive tax system if the timing of withdrawal puts investors in a lower tax bracket $\left(\tau_{0}>\tau_{1}\right)$. As illustrated by Burman, Gale and Weiner (2001), the 
advantage of front-loaded plans lies in the benefit from the much lower tax rate most people face in retirement. Back-loaded plans, on the other hand, give taxpayers larger capacity to shelter funds than front-loaded plans, given equal contribution limits.

Without loss of generality, hereafter, I assume that all TDA contributions are income tax deductible and are capped by an annual limit, that interest accrues tax free, that withdrawals are taxed at the then-prevailing income tax rate, and that early withdrawals are subject to penalty. These assumptions are in line with current regulations.

\subsection{Asset Locations - Saving for Retirement or for Liquidity}

A simple horse race between returns on CSA and TDA investments will help illustrate the impact of the TDA tax structure on asset location decisions. Let $r, \tau$, and $\tau_{w}$ denote the net interest rate, flat income tax rate (for ease of exposition in this section) and penalty rate on early withdrawals, respectively. A pre-tax dollar can be invested either in CSAs or in TDAs. A non-deductible CSA investment has a principal $\$ 1(1-\tau)$

and accrues at after-tax rate of return $r(1-\tau)$. It yields the following gross return in $n$ years:

$$
\$ 1(1-\tau)[1+r(1-\tau)]^{n}
$$

A tax-deferred TDA investment has the entire dollar as principal and enjoys a pre-tax rate of return on interest. For the same horizon it yields the following gross return, after paying income tax and penalty (if applicable) upon withdrawal:

$$
\$ 1(1+r)^{n}(1-\tau)\left(1-\tau_{w}\right) .
$$


It is apparent that TDAs are superior to CSAs if withdrawals are penalty free $\left(\tau_{w}=\right.$ 0). Saving in TDAs is also preferable if the investment is held sufficiently long so that the tax-deferring benefit more than offsets the penalty, which occurs if

$$
n \geqslant n^{*} \equiv \frac{\ln \left(1-\tau_{w}\right)}{\ln \left[\frac{1+r(1-\tau)}{1+r}\right]} .
$$

where $n^{*}$ is the break-even holding period of TDA assets. A little algebra reveals that

$$
\begin{aligned}
& \frac{\partial n^{*}}{\partial \tau_{w}}>0 \\
& \frac{\partial n^{*}}{\partial \tau}<0 . \\
& \frac{\partial n^{*}}{\partial r}<0
\end{aligned}
$$

A longer saving horizon is required in order to lock in tax subsidies sufficient to offset a higher early withdrawal penalty. Conversely, the more significant the tax shelter, the sooner households can harvest higher yields by investing in TDAs. For instance, if $r=6 \%, \tau=25 \%$, and $\tau_{w}=10 \%$, the investment horizon required to make TDA investment preferable despite the withdrawal penalty will be almost 11 years, while $\tau_{w}=15 \%$ and $\tau=30 \%$ will require $n \geqslant 16$ and $n \geqslant 9$, respectively.

This exercise shows that the investment horizon matters for asset location choice. The early withdrawal penalty could make TDA investment ex post unattractive relative to CSAs, unless the probability of early withdrawal is sufficiently small. TDAs are preferable when savings are for retirement, a long term objective, while CSAs are the optimal location to establish a buffer against immediate shocks. This is reflected in the fact that (1) is greater than (2) when $n=1$, a short horizon. The simple comparison of (1) and (2) suggests that the wealth-maximizing investment strategy 
might be to allocate all incremental savings into TDAs, if feasible, once a certain liquidity buffer has been established in CSAs.

\section{A Life Cycle Model}

In this section, I outline a rich life-cycle model to capture the labor supply and consumption behaviors of individuals who are equipped with both TDAs and CSAs and who save for liquidity reasons, retirement, and bequests.

\subsection{Preferences}

Households have a maximum life span of $T$ years, at which age death is certain. At each age $t \leqslant T$, households derive utility from consumption, leisure and potential bequests. The preferences are described by the following expected lifetime utility function

$$
E_{0} \sum_{t=0}^{T} \beta^{t}\left[\Psi_{t} u\left(c_{t}, l_{t}\right)+\left(1-\Psi_{t}\right) \Gamma\left(w_{t}\right)\right]
$$

where $E_{0}$ is the expectation operator; $\beta$ is the subjective discount factor; $\Psi_{t}$ is the unconditional survival probability, specifically, $\Psi_{t}=\left(\prod_{j=1}^{t} \psi_{j}\right)$, with $\psi_{t} \in(0,1)$ being the survival probability at age $t$ conditional on being alive at age $t-1$, given $\psi_{0}=1$;

and $c_{t}$ and $l_{t}$ are consumption and leisure, respectively. The period utility function is constant relative risk aversion (CRRA) over consumption and logarithmic over leisure:

$$
u\left(c_{t}, l_{t}\right)=\frac{c_{t}^{1-\gamma}-1}{1-\gamma}+\eta\left(t, h, e_{t}\right) \ln \left(l_{t}\right)
$$


where $\gamma>0$ indicates an individual's relative risk aversion. The propensity for individuals to increase savings as a reaction to uncertainty of income is embedded in the CRRA function, where the positive third derivative serves as a sufficient (and necessary) condition for this precautionary motive. The weight on disutility of work, $\eta\left(t, h, e_{t}\right)$, is dependent on age $t$, health $h$, and average wages $e_{t}$ (defined in (10) to proxy earnings ability) to reflect that agents' attitude towards leisure is time-varying with age and that healthy and well-paid agents tend to view work as less burdensome (Autor and Duggan, 2003). Such modeling strategy of heterogeneity in preferences follows the spirit of Rust (2005). Households also derive utility from bequests in case of death, defined as a function of the terminal wealth $w_{t}$,

$$
\Gamma\left(w_{t}\right)=\kappa \frac{w_{t}^{1-\gamma}-1}{1-\gamma}
$$

where the parameter $\kappa$ measures the attitude towards bequests.

\subsection{Income and Social Security}

I introduce a stochastic labor income process, which is required to generate precautionary savings in CSAs, as described in the literature on "buffer stock" savings (see Deaton (1991), and Carroll (1992), among others). This is also motivated by the observation that explicit insurance markets for labor income are not well developed. 
Specifically, the labor income process is expressed in (10).

$$
\begin{aligned}
\ln \left(y_{t}\right) & =\alpha_{0}+\alpha_{1} \ln \left(e_{t}\right)+\alpha_{2} t+\alpha_{3} t^{2}+\varepsilon_{t} \\
\varepsilon_{t} & =\rho \varepsilon_{t-1}+\nu_{t}, \nu_{t} \sim N\left(0, \sigma_{\nu}^{2}\right) \\
y\left(l_{t}\right) & =\left(1-l_{t}\right) y_{t}
\end{aligned}
$$

First, the earnings contains a deterministic component as a function of age $t$ and average earnings $e_{t}$ (defined below as a proxy for AIME), which captures the lifecycle trend in wages, an approach suggested by Rust and Phelan (1997). ${ }^{5}$ Second, randomness of earnings is introduced through shocks $\varepsilon^{\prime} \mathrm{s}$, with $\rho$ controlling the degree of persistence. Accumulation of shocks makes life-cycle earnings profiles vary across individuals, which is an important source of income heterogeneity. Third, given the above "exogenous" factors, final income $y\left(l_{t}\right)$ is endogenously determined by the level of labor supply $\left(1-l_{t}\right)$. The labor flexibility implies an endogenous decision on the timing of retirement, which is assumed to be reversible at no cost prior to a mandatory retirement age, $t^{m}$.

Social Security benefits, called Primary Insurance Amount (PIA), are determined by the Average Indexed Monthly Earnings (AIME). AIME is in practice calculated as the average of the 35 highest years of earnings. In order to keep the computation tractable while preserving the essence of Social Security rules, the annualized AIME

\footnotetext{
${ }^{5}$ This modeling strategy has at least three merits. First, the distribution of $e_{t}$ effectively captures fixed effects across individuals since $e_{t}$, as a proxy of AIME, follows a rather gradual evolution and thus reflects a permanent component of wages. Second, this setup is computationally efficient: with $e_{t}$ already being carried as a state variable, a single solution of the model is sufficient for simulations to generate income heterogeneity given various initial values for $e_{1}$. Third, the specification of $e_{t}$ and $t$ fits the real life-cycle trend of wages quite well, which is the ultimate objective of such modeling.
} 
in this model, denoted by $e_{t}$, is measured as the average of all earnings prior to retirement. Specifically,

$$
e_{t+1}=\frac{t e_{t}+\min \left[y\left(l_{t}\right), y^{\max }\right]}{t+1}
$$

where $y^{\max }$ is the maximum of earnings subject to payroll tax and counted toward $e$.

The PIA, denoted by $b$, is a concave piece-wise function of the $\operatorname{AIME}\left(e^{*}\right)$ achieved at the claim age $\left(t^{*}\right)$. For $t=t^{*}, t^{*}+1, t^{*}+2, \ldots, T$,

$$
b= \begin{cases}\max \left\{b^{\min }, \alpha_{0} e^{*}\right\}, & \text { if } e^{*}<B_{1} \\ \alpha_{1}+\alpha_{2}\left(e^{*}-B_{1}\right), & \text { if } B_{1} \leqslant e^{*}<B_{2} \\ \alpha_{3}+\alpha_{4}\left(e^{*}-B_{2}\right), & \text { if } \quad B_{2} \leqslant e^{*}\end{cases}
$$

where $B_{1}$ and $B_{2}$ are referred to as the bend points, and $b^{\min }$ is the minimum floor of Social Security benefits. Individuals are assumed to make separate decisions with regard to the timing of retirement and take-up of Social Security benefits. They can elect to claim Social Security provided that they have reached the early retirement age, $t^{e}$. However, benefits are higher if individuals wait until a normal retirement age, $t^{n}$, where $t^{e}<t^{n}<t^{m}$. Social Security claiming is irreversible; that is, once individuals begin receiving Social Security they are locked into their PIA annuity for their remaining lifetime. According to current regulations, early claims prior to age $t^{n}$ are granted lower benefits, while delayed claims past $t^{n}$ get credit. Both adjustments are approximately actuarially fair for the average person. In addition, Social Security benefits are subject to an earnings test if individuals are younger than $t^{m}$. Early claims face a higher earnings test tax rate and a lower exempt minimum compared with delayed claims. Specifically, Social Security benefits are reduced by 
$\tau^{0} \max \left\{y\left(l_{t}\right)-\bar{y}^{0}, 0\right\}$ for claims between ages $t^{e}$ and $t^{n}$, and by $\tau^{1} \max \left\{y\left(l_{t}\right)-\bar{y}^{1}, 0\right\}$ for claims between ages $t^{n}$ and $t^{m}$, with $\tau^{0}>\tau^{1}$ and $\bar{y}^{0}<\bar{y}^{1}$. Obviously, the reduction is no larger than $b$.

\subsection{The Household Optimization Problem}

Let $a$ and $q$ denote assets in CSAs and TDAs, respectively. I impose the following simple liquidity restrictions on CSAs and TDAs via (13)-(14). These conditions prevent households from capitalizing or borrowing against future labor income or retirement wealth.

$$
\begin{aligned}
& a_{t} \geqslant 0, \forall t \\
& q_{t} \geqslant 0, \forall t
\end{aligned}
$$

Households can contribute to TDAs up to $\xi$ percent of labor income or a specific ceiling, $L$, whichever is smaller. They may instead choose to draw down TDA assets. Formally, if the TDA transaction in dollars is denoted by $x_{t}$, then

$$
-(1+r) q_{t} \leqslant x_{t} \leqslant \min \left\{\xi y\left(l_{t}\right), L\right\}
$$

where positive values of $x_{t}$ imply contributions, and negative values represent withdrawals. Condition (15) mandates that TDA contributions are not feasible when there is no labor income $\left(y\left(l_{t}\right)=0\right)$, which is consistent with tax regulations in practice. Contributions are tax deductible, while early withdrawals are subject to penalty at rate $\tau_{w}$ prior to the penalty-free age, $t^{f}$. Households need to pay federal and state income taxes on TDA withdrawals at then-prevailing rates regardless of age. 
Households' dynamic budget constraints for CSAs and TDAs evolve as follows:

$$
\begin{aligned}
a_{t+1}= & (1+r) a_{t}+y\left(l_{t}\right)+b-\left(1-\lambda_{t} \tau_{w}\right) x_{t}-c_{t} \\
& -\tau\left(y\left(l_{t}\right), x_{t}, r a_{t}, b\right)-\tau_{s} \min \left\{y^{\max }, y\left(l_{t}\right)\right\} \\
q_{t+1}= & (1+r) q_{t}+x_{t}
\end{aligned}
$$

where $\lambda_{t}$ is an indicator function that is equal to 1 if $x_{t}<0$ and $t<t^{e}$, and 0 otherwise; $\tau_{s}$ denotes the payroll tax at rate, and $\tau\left(y\left(l_{t}\right), b, x_{t}, r a_{t}\right)$ encompasses all other taxes including a progressive tax on labor income, the Earned Income Tax Credit (EITC), income taxes (or refunds) on TDA withdrawals (contributions), taxes on CSA interest, taxes on income-adjusted Social Security benefits, and taxes due to the earnings test. It should be stressed that CSA assets accrue at an after-tax rate while TDAs accrue tax free. Early TDA withdrawals are costly due to the penalty $\left(\tau_{w} x_{t}\right)$ in addition to the income tax.

The consumer's problem is to maximize the discounted expected lifetime utility in (7), given initial endowment of wealth, subject to the short-selling constraints (13)(14) and the dynamic budget constraints (15)-(17). The beginning-of-period state variables are $\Lambda_{t}=\left\{t, a_{t}, e_{t}, q_{t}, \varepsilon_{t}, z_{t}^{s}\right\}$, and the choice variables $\left\{c_{t}, l_{t}, x_{t}, z_{t}^{d}\right\}$, where $z_{t}^{s}$ and $z_{t}^{d}$ are the Social Security claim status and claim decision, respectively. Individuals must decide on consumption, $c_{t}$, labor supply, $l_{t}$, asset allocation between TDAs and CSAs, $x_{t}$, and whether to claim Social Security, $z_{t}^{d}$. It should be noted that labor earnings are unknown due to their stochastic nature when consumption decisions are made. Individuals in the model are thus restricted to consume no more than their current tangible wealth in CSAs and TDAs, net of taxes and early withdrawal 
penalty if applicable. ${ }^{6}$ This implies that they cannot borrow against future earnings. Specifically,

$$
c_{t} \leqslant(1+r)\left(a_{t}+q_{t}\right)+b-\tau\left(0,(1+r) q_{t}, r a_{t}, b\right)-\lambda_{t} \tau_{w}(1+r) q_{t}
$$

However, realizations of earnings must be revealed when individuals are making TDA contributions since they need to know the limit imposed by $x_{t} \leqslant \min \left\{\xi y\left(l_{t}\right), L\right\}$. Otherwise, there would exist cases in which TDA contributions could exceed labor earnings, yielding negative CSA balances in violation of condition $a_{t} \geqslant 0$. Let $V\left(\Lambda_{t}\right)$ be the indirect value function for the dynamic programming problem. Then,

$$
V\left(\Lambda_{t}\right)=\max _{c_{t}, l_{t}, x_{t}, z_{t}^{d}}\left\{u\left(c_{t}, l_{t}\right)+\beta\left[\psi_{t+1} E_{t} V\left(\Lambda_{t+1}\right)+\left(1-\psi_{t+1}\right) E_{t} \Gamma\left(w_{t+1}\right)\right]\right\}
$$

subject to constraints (13)-(17), where $E_{t}$ is the expectation over the distribution of $\Lambda_{t+1}$ conditional on information at $t$. Terminal wealth $w$ is the combined TDA and CSA assets.

\section{Some Heuristic Findings}

This complex dynamic programming problem calls for numerical solution and simulation of life-cycle behavior. Before presenting numerical results, it is worth highlighting some heuristic findings in a simplified version of the model in which I assume a flat and constant income tax rate $\tau$, maintaining the assumptions that TDAs accrue tax free and are subject to early withdrawal penalty. These simplifications preserve the

\footnotetext{
${ }^{6}$ This restriction implies that part of CSA balances are assets-in-advance for transaction purposes.
} 
main characteristics of TDAs, while allowing for a progressive tax system would further strengthen the following analysis. Appendix 1.A outlines the derivation of the following findings.

\subsection{Consumption}

The first order necessary conditions of the utility maximization problem with respect to $a_{t+1}$ and $q_{t+1}$ at age $t$ are (20) and (21), respectively.

$$
\begin{aligned}
u_{c}^{\prime}\left(c_{t}, l_{t}\right)= & \beta[1+(1-\tau) r] E_{t}\left[\psi_{t+1} u_{c}^{\prime}\left(c_{t+1}, l_{t+1}\right)\right. \\
& \left.+\left(1-\psi_{t+1}\right) \Gamma^{\prime}\left(w_{t+1}\right)\right]+E_{t} \mu_{t+1}^{a} \\
\left(1-\lambda_{t} \tau_{w}\right) u_{c}^{\prime}\left(c_{t}, l_{t}\right)= & \beta(1+r) E_{t}\left[\left(1-\lambda_{t+1} \tau_{w}\right) \psi_{t+1} u_{c}^{\prime}\left(c_{t+1}, l_{t+1}\right)\right. \\
& \left.+\left(1-\psi_{t+1}\right) \Gamma^{\prime}\left(w_{t+1}\right)\right]-\mu_{t}^{L}+(1+r) E_{t} \mu_{t+1}^{L}+E_{t} \mu_{t+1}^{q}(
\end{aligned}
$$

where $\mu_{t}^{a}$ and $\mu_{t}^{q}$ are the Lagrange multipliers on the non-negativity constraints for CSAs and TDAs; and $\mu_{t}^{L}$ is the Lagrange multiplier on the contribution limit.

Condition (20) is the Euler equation with respect to $a_{t+1}$. It implies that households will balance consumption and CSA saving so that the marginal utility of a unit of current consumption is equal to the marginal benefit of saving the same unit, which includes the discounted marginal utility of future consumption or bequests and the expected benefit from avoiding the liquidity constraint $\left(E_{t} \mu_{t+1}^{a}\right)$.

Condition (21) is the Euler equation with respect to $q_{t+1}$, which embodies a similar intuition for the optimal allocation between consumption and saving in TDAs. The difference lies in the fact that the TDA savings have a higher rate of return and the 
fact that the intertemporal optimization regarding TDAs might be inhibited by the contribution limit. The marginal benefit of contributing in period $t$ (thus $\lambda_{t}=0$ ) is equal to the expected marginal utility of future consumption or bequests, plus the expected gain from avoiding the contribution limit and the liquidity constraint next period. Proposition 1 follows from further examination of (21).

Remark 1. (i) The expected marginal benefit of TDA saving is lowered by the withdrawal penalty when it applies (i.e. when $\lambda_{t+1}=1$ ); (ii) An individual may not be able to fully realize the benefit of contributing due to the contribution limit (i.e. when $\mu_{t}^{L}>0$ ); and (iii) The marginal benefit of withdrawing (thus $\lambda_{t}=1$ ) in period $t$ is shrunk by the penalty and carries a higher opportunity cost in terms of lower wealth accumulation for future.

Tax advantages induce wealth accumulation through TDAs, while the precautionary motive keeps savings in CSAs. The balance is struck by combining (20) and (21). The resulting equation (see Appendix 1.A) implies that an optimal interior asset allocation between CSAs and TDAs is reached when a dollar contribution to CSAs or TDAs brings the same level of marginal expected utility (otherwise a corner solution emerges, so that contributions will be made in only one type of account). Some simplification yields a straightforward interpretation for a special case in which the individual contributes to TDAs at age $t$ (thus $\lambda_{t}=0$ ) and the individual's future withdrawals are not subject to penalty (i.e. $\lambda_{t+1}=0$ with probability one). The 
following condition holds in this special case:

$$
\begin{aligned}
& \beta \tau r E_{t}\left[\psi_{t+1} u_{c}^{\prime}\left(c_{t+1}, l_{t+1}\right)+\left(1-\psi_{t+1}\right) \Gamma^{\prime}\left(w_{t+1}\right)\right] \\
= & E_{t} \mu_{t+1}^{a}+\mu_{t}^{L}-(1+r) E_{t} \mu_{t+1}^{L}-E_{t} \mu_{t+1}^{q}
\end{aligned}
$$

The left hand side of equation (22) measures the advantage of contributing to TDAs rather than to CSAs, which is the discounted marginal expected utility due to the tax shelter on interest (via the term $\tau r$ ). Note that $E_{t} \mu_{t+1}^{L} \geqslant 0$ and $E_{t} \mu_{t+1}^{q} \geqslant 0$ and note also that the left hand side of equation (22) is strictly positive. The relative tax advantage for TDAs in this special case of no withdrawal penalties thus implies either a binding contribution limit $\left(\mu_{t}^{L}>0\right)$ or a binding constraint on borrowing against $\operatorname{CSAs}\left(E_{t} \mu_{t+1}^{a}>0\right)$.

Remark 2. Absent withdrawal penalty, all individuals would contribute to the limit.

\subsection{Saving Rules}

Another way of seeing the impact of TDA rules on the allocation of savings heuristically is to examine the marginal value of CSA and TDA wealth. Applying the Envelope Theorem with respect to $a_{t}$ and $q_{t}$, respectively, to the indirect value function and shifting one period forward produces the following conditions.

$$
\begin{aligned}
E_{t} V_{a}^{\prime}\left(\Lambda_{t+1}\right)= & {[1+r(1-\tau)] E_{t}\left[\mu_{t+1}^{B}+\beta\left(1-\psi_{t+1}\right) \Gamma^{\prime}\left(w_{t+1}\right)\right]+E_{t} \mu_{t+1}^{a} } \\
E_{t} V_{q}^{\prime}\left(\Lambda_{t+1}\right)= & (1+r) E_{t}\left[\mu_{t+1}^{B}\left(1-\lambda_{t+1} \tau_{w}\right)\right. \\
& \left.+\beta\left(1-\psi_{t+1}\right) \Gamma^{\prime}\left(w_{t+1}\right)+\mu_{t+1}^{L}\right]+E_{t} \mu_{t+1}^{q}
\end{aligned}
$$


where $\mu_{t+1}^{B}$ is the Lagrange multiplier on the dynamic budget constraint in period $t+1$. Several interesting findings are exhibited in Proposition 3.

Remark 3. (i) Absent a sufficient CSA buffer, it is not optimal to overinvest in TDAs. Shocks materialized next period may force early withdrawal (hence $\lambda_{t+1}=1$ and $\left.\mu_{t+1}^{L}=0\right)$, which makes after-penalty TDAs inferior to CSAs since $E_{t} V_{a}^{\prime}\left(\Lambda_{t+1}\right)>$ $E_{t} V_{q}^{\prime}\left(\Lambda_{t+1}\right)$. (ii) With a sufficient CSA buffer, savings for retirement should be allocated to TDAs since $E_{t} V_{q}^{\prime}\left(\Lambda_{t+1}\right)>E_{t} V_{a}^{\prime}\left(\Lambda_{t+1}\right)$ when $\lambda_{t+1}=0$ with probability 1. (iii) The presence of a bequest motive encourages both CSA and TDA savings, with the marginal benefit of TDA savings enhanced more substantially simply because $1+r>1+r(1-\tau)$. (iv) The stronger the bequest motive, the more valuable are TDAs compared with CSAs since

$$
\frac{d E_{t} V_{q}^{\prime}\left(\Lambda_{t+1}\right)}{d E_{t} \Gamma^{\prime}\left(w_{t+1}\right)}>\frac{d E_{t} V_{a}^{\prime}\left(\Lambda_{t+1}\right)}{d E_{t} \Gamma^{\prime}\left(w_{t+1}\right)}
$$

Another way of viewing (23) and (24) heuristically is that they imply an optimal sequencing of withdrawals from TDAs and CSAs, should the household need to dissave. For a given-sized transaction and absent withdrawal penalty, the opportunity cost of drawing down TDAs is larger than that of drawing down CSAs by a factor of $(1+r) /[1+r(1-\tau)]$. In addition, when a withdrawal penalty exists, households have to increase TDA withdrawals by a factor of $1 /\left(1-\tau_{w}\right)$ to get the same level of financing.

Remark 4. TDA withdrawals are more costly and individuals should first exhaust CSA funds before tapping TDAs. 


\subsection{Retirement Effect of TDAs}

Comparative statics help illustrate the impact of CSA and TDA wealth on leisure choice. A little algebra in Appendix 1.A shows that

$$
\begin{aligned}
& \frac{\partial l_{t}}{\partial a_{t}}>0 \\
& \frac{\partial l_{t}}{\partial q_{t}}>0
\end{aligned}
$$

These inequalities imply that higher wealth accumulated to date, either in CSAs or TDAs, tends to induce more leisure or even complete exit from labor force (retirement). Further analysis (in Appendix 1.A) reveals that

$$
\frac{\partial l_{t}}{\partial q_{t}}>\frac{\partial l_{t}}{\partial a_{t}}
$$

which is particularly true once the agent is old enough that TDA withdrawals are penalty free. The inequality in (27) implies that TDA wealth has a larger impact on labor supply and that early retirement becomes easier with TDA wealth accumulation.

Remark 5. Leisure is a normal good and the higher pre-tax rate of return on TDAs provides a greater income effect, which encourages more retirement.

\section{$5 \quad$ Numerical Analysis}

I now return to the fully-loaded version of the model and use numerical methods to analyze consumers' saving, labor supply, and Social Security claim decisions. The computation begins by discretizing the continuous state variables. The utility maximization problem is then solved backward from age $T$ to age $t_{1}$ for all feasible combi- 
nations of state grid points and realizations of random variables. The optimal decision rules are recorded along this backward process. Large scale Monte Carlo simulations are finally carried out to generate average life-cycle profiles based on the decision rules derived above. See Appendix 1.B for details of the solution method.

\subsection{State and Choice Variables}

Some explanation of the discretization of variables is in order. Following Rust (2005) and Gustman and Steinmeier (2003), I introduce limited labor flexibility. Specifically, I assume discrete leisure choice, i.e. $l_{t} \in\{1, .817, .543\}$, where full leisure (no work) is normalized to 1 , and leisure for part-time and full-time work is .817 and .543 , respectively. ${ }^{7}$ This assumption, in spite of its restriction on labor adjustment, may reflect the real world given the observation that legal and institutional impediments make phased retirement difficult to achieve (Penner, Perun and Steuerle (2002)). Ruhm (1990) finds that transition through bridge jobs or part-time employment is common for employees who desire partial retirement. It is assumed that individuals make discretionary decisions on labor supply before age 70 and that all employees must retire no later than 70 .

The Social Security payment status $z_{t}^{s}$ is either 0 , which indicates non-eligibility or non-claiming, or one of $\{62,63, \ldots 70\}$, which indicates the age when an individual starts to claim and receive Social Security benefits. The Social Security claim decision

\footnotetext{
${ }^{7}$ Assuming that 12 hours a day are available for discretionary work/leisure, and assuming 2000 hours a year (40hours*50weeks) are required for a full-time job, then $l_{t}=(12 * 365-2000) /(12 * 365)=$ .543. Similarly, assuming 800 hours for a part-time job generate $l_{t}=(12 * 365-800) /(12 * 365)=.817$.
} 
$z_{t}^{d}$ indicates individuals' choices conditional on not previously claiming benefits: to claim $\left(z_{t}^{d}=1\right)$ or not to claim $\left(z_{t}^{d}=0\right)$. Agents who claim receive the annuity value determined at the first claim age for their remaining life span. Agents cannot reverse their decision to claim. The actually disposable value of Social Security benefits may vary due to the earnings test.

Households can elect to claim Social Security when $t \in\{62,63, \ldots 70\}$. The end points are the early and the mandatory retirement age, respectively. No Social Security benefit may be granted prior to 62 . Early claims prior to the normal retirement/claim age 65 receive benefits reduced by an approximately actuarially fair factor of $6.67 \%$ per year prior to 65 . For instance, a claim at age 62 will receive $80 \%$ of the normal benefit. ${ }^{8}$ Delayed claims past 65 are awarded delayed credit, which is not applicable beyond age 70 . The credit factor is assumed to be $5 \%$ for each year delayed. ${ }^{9}$ Benefits between ages 62 and 70 may be partially or entirely taxed away depending on the level of labor income. The earnings test prior to age 65 is more stringent than after, which is reflected in the earnings test tax rates $\left(\tau^{0}=50 \%\right.$ and $\left.\tau^{1}=33.3 \%\right)$ and the exempt minima $\left(\bar{y}^{0}=\$ 10,800\right.$ and $\left.\bar{y}^{1}=\$ 17,000\right) \cdot{ }^{10}$ These assumptions are largely consistent with current Social Security rules.

\footnotetext{
${ }^{8}$ The normal retirement age is now increasing gradually to 67 for individuals born in 1960 or later. The benefit reduction for retirement at 62 will rise to $30 \%$ for those born in 1960 or later.

${ }^{9}$ In practice, the annual delayed retirement credit varies from $3 \%$ to $8 \%$ by birth year. Individuals born in 1924 receive $3 \%$ more benefit per delayed year. The annual credit increases by $0.5 \%$ for each additional two years after birth year 1924 until it reaches 8\% for those born in 1943 or later.

${ }^{10}$ The earnings test for ages 66 to 69 has been recently eliminated. Some researchers list this policy change as one of the reasons for the recently observed increase in labor supply among the old.
} 
Table 1. Summary of State Variables

\begin{tabular}{lll}
\hline \hline Symbol & Description & Type \\
\hline$t$ & Age & discrete, $t \in\{21,22, \ldots 90\}$ \\
$a_{t}$ & CSA savings & continuous, $a_{t} \in[0, \infty)$ \\
$e_{t}$ & AIME & continuous, $e_{t} \in[0,72.6]$ \\
$q_{t}$ & TDA savings & continuous, $q_{t} \in[0, \infty)$ \\
$\varepsilon_{t}$ & Persistent shock & Markov chain \\
$z_{t}^{s}$ & S.S. claim status & discrete, $z_{t}^{s} \in\{0,62,63, \ldots 70\}$ \\
\hline \hline
\end{tabular}

Table 2. Summary of Choice Variables

\begin{tabular}{lll}
\hline \hline Symbol & Description & Type \\
\hline$c_{t}$ & Consumption & continuous \\
$l_{t}$ & Leisure choice & discrete, $l_{t} \in\{1, .817, .543\}$ \\
$x_{t}$ & Asset allocation & continuous \\
$z_{t}^{d}$ & S.S. claim decision & discrete, $z_{t}^{d} \in\{0,1\}$ \\
\hline \hline
\end{tabular}

\subsection{Parameter Calibrations}

Individuals in the model make decisions starting at age 21 and can live up to age 90. The conditional survival probabilities, $\psi_{t}$, are the death rates for males in the Decennial Life Tables maintained by the U.S. Centers for Disease Control and Prevention. The value of the subjective discount factor, $\beta$, has been usually taken to be less than unity to reflect impatience (e.g. Auerbach and Kotlikoff, 1987 and Hubbard and Judd, 1987), although empirical evidence has also suggested values larger than unity (Hurd, 1989). The discount factor $\beta$ is set to be 0.98 in this model. There is a wide range of empirical estimates for the elasticity of intertemporal substitution, $1 / \gamma$ (the reciprocal of the coefficient of relative risk aversion). Hall (1988) believes $1 / \gamma$ very close to zero. Kydland and Prescott (1982) calibrate $1 / \gamma$ to 0.66. Carroll (2001) views $\gamma$ between $[1,5]$ as generally plausible. I set $1 / \gamma=0.73$ to reflect moderate risk aversion. I assume as a benchmark that there is a modest bequest motive, setting $\kappa=0.2$. 
The weight on disutility of work, $\eta\left(t, h, e_{t}\right)$, is assumed to increase with age $t$ and to decrease with $e_{t}$, a proxy of earnings ability. The notion that the utility function changes over time because of changes in disutility of work is supported by Autor and Duggan (2003) who show that disability rates increase with age. The weight on leisure $\eta\left(t, h, e_{t}\right)$ also increases with the deterioration of health $h$, a notion supported by the findings by Duggan, Singleton and Song (2005). This case is explored in Section 1.6. Graphically, Figure 1 shows the heterogeneity in preferences introduced by the weight on leisure.

The coefficients governing the life-cycle trend of earnings in (10) are estimated on the restricted Social Security earnings data from HRS and are reported in Table 3. The persistent shocks are approximated by a 2 -state Markov chain with $\sigma_{\nu}^{2}=.06$ and $\rho=.935$. These shock parameters are obtained from Storesletten, Telmer and Yaron (1998). Heathcote, Storesletten, and Violante (2004) report similar estimates. Their common emphasis is the importance of persistent and transitory shocks in forming individuals' earnings profiles. Figure 2 shows the heterogeneity in income and the corresponding AIME generated by this formulation.

The tax structure is constant over the life cycle. The income tax is intended to mimic the 2000 individual tax code, which includes a progressive Federal income tax schedule with tax brackets of $15,28,36$ and 39.6 percent and a flat $5 \%$ state and local tax. ${ }^{11}$ The model also incorporates a detailed Earned Income Tax Credit (EITC) applicable

\footnotetext{
${ }^{11}$ The marginal tax rate according to 2000 Federal tax code is 15 percent on income below $\$ 26,250$, 28 percent on income between $\$ 26,251$ and $\$ 63,550,31$ percent on income between $\$ 63,551$ and $\$ 132,600,36$ percent on income between $\$ 132,601$ and $\$ 288,350$, and 39.6 percent on income above $\$ 288,350$.
} 


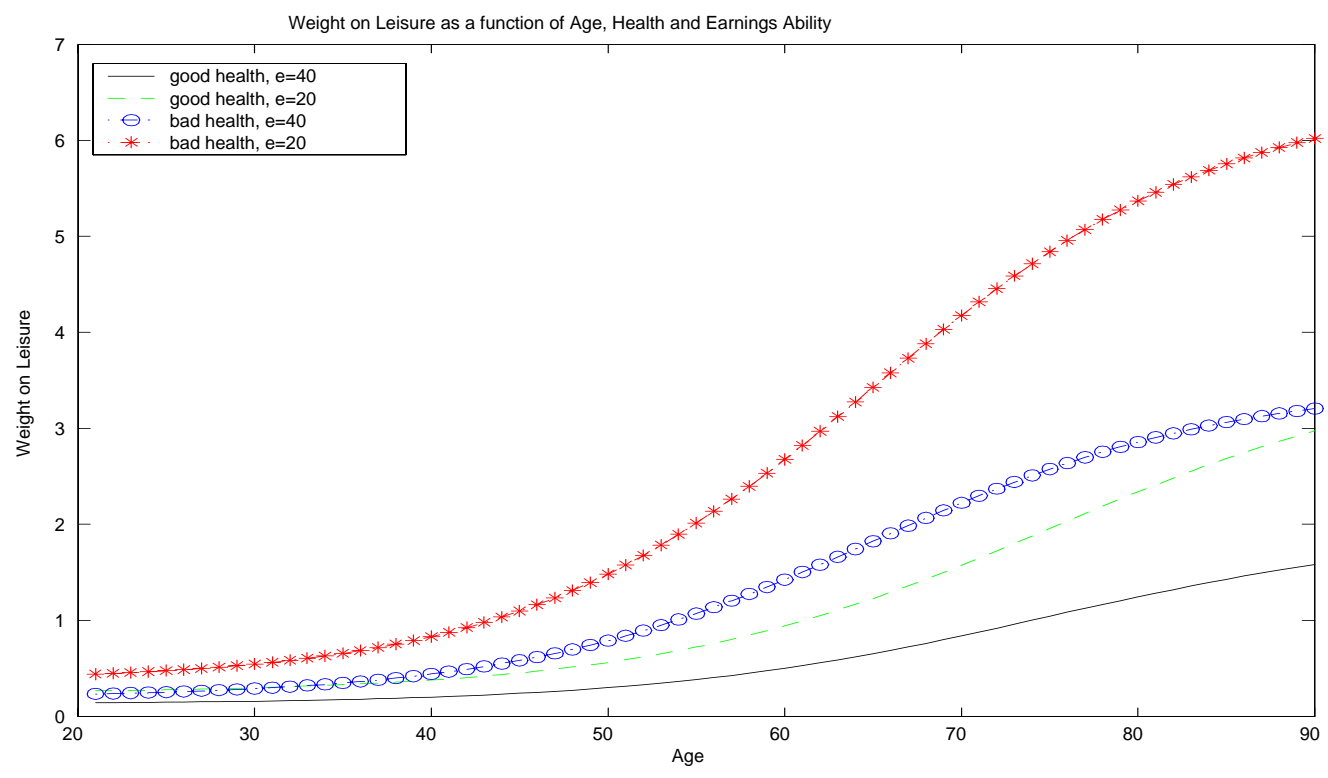

Figure 1: Heterogeneity in Preferences
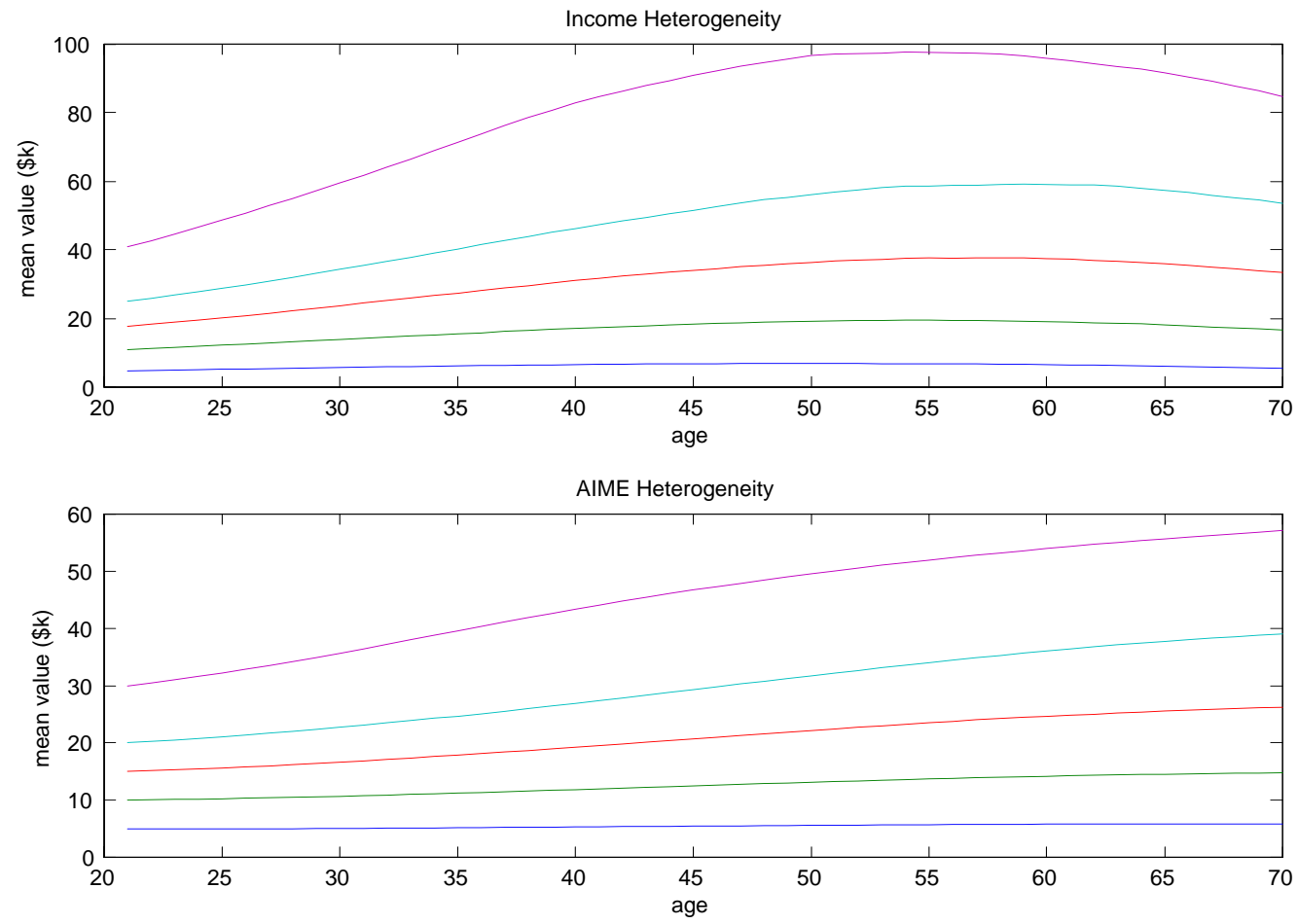

Figure 2: Heterogeneity in Income and AIME 
to low income individuals. The payroll tax rate, $\tau_{s}$, is $6.2 \%$ for Old Age, Survivors, and Disability Insurance (OASDI) and is applied to earnings up to a maximum of $\$ 76,200 .{ }^{12}$ The parameter values and bend points determining PIA in (12) follow the 2000 Social Security regulations. ${ }^{13}$ The before tax return on savings is set to be $4 \% .{ }^{14}$

According to the Economic Recovery Tax Act (ERTA) of 1981, individuals who are $59 \frac{1}{2}$ or older are allowed to draw on their IRAs without penalty. Thus the penalty free age in the model is $t^{f}=60$. The TDA contribution ceiling $L$ is equal to $\$ 10,500$, which was the value of the elective contribution limit on $401(\mathrm{k})$ plans in $2000 .{ }^{15}$ In addition, the Employee Retirement Income Security Act (ERISA) regulates that employer and employee tax-deferred contributions combined can not exceed 25 percent of total earned income. These rules apply as well to other defined contribution plans, such as IRAs and Keogh plans. Many employers impose even tighter limits in the range of $10-15 \% \cdot{ }^{16}$ Here I set $\xi=25 \%$. Early withdrawals are subject to a 10 percent penalty according to ERISA. Therefore, I set $\tau_{w}=10 \%$. The regulatory rules on spe-

\footnotetext{
${ }^{12} \mathrm{I}$ abstract from the Medicare tax since no medical costs are explicitly modeled. In practice the Medicare tax rate (HI) is $1.45 \%$. The employer and employee combined rate for OASDI and $\mathrm{HI}$ is $15.3 \%$.

${ }^{13}$ The values for PIA formula in Table 3 are monthly figures. PIA parameters are calculated as follows: $\alpha_{1}=\alpha_{0} B_{1}=477.9, \alpha_{3}=\alpha_{1}+\alpha_{2}\left(B_{2}-B_{1}\right)=1332.6$.

${ }^{14}$ This rate of return implicitly assumes a portfolio composed of both stocks and bonds. Scholz, Seshadri, and Khitatrakun (2004) report 7.6\% as the average real stock market return between 1947 and 1996 and $0.8 \%$ as the average real return on 3-month Treasury bills (footnote 16).

${ }^{15}$ IRA contribution limits vary by year and age: they are $\$ 3,000$ in $2002-2004, \$ 4,000$ in 2005-2007 and $\$ 5,000$ in 2008; and individuals over 50 have a further $\$ 500$ in 2002 and $\$ 1,000$ in 2006. Limits will be indexed for inflation after 2008. Traditional IRA contributions are fully tax deductible if the owner does not participate in a 401(k) or other qualified retirement plan; otherwise the deductibility may decline to zero depending on the owner's modified adjusted gross income (AGI).

${ }^{16}$ See Engen, Gale, and Scholz (1994) (page 89).
} 
cial retirement accounts generally prohibit early withdrawals except in some special circumstances. ${ }^{17}$

Table 3. Parameter Calibrations

\begin{tabular}{ll|ll}
\hline \hline Preferences & & Ages & \\
\hline$\beta=0.98$ & discount factor & $t_{1}=21$ & starting age \\
$\gamma=1.37$ & CRRA value & $t^{f}=60$ & penalty free \\
$\eta\left(t, h, e_{t}\right)$ & see text & $t^{e}=62$ & early retirement \\
$\kappa=0.2$ & bequest factor & $t^{n}=65$ & normal ret. \\
$\Psi, \psi$ & survival rate & $t^{m}=70$ & mandatory ret. \\
$r=.04$ & interest rate & $T=90$ & max. life span \\
\hline PIA Formula & & Earnings Process \\
\hline$b^{\text {min }}=\$ 300$ & $\alpha_{0}=.9$ & $\delta_{0}=-1.05$ & $\delta_{1}=1.20$ \\
$\alpha_{1}=\$ 478$ & $\alpha_{2}=.32$ & $\delta_{2}=.04$ & $\delta_{3}=-.0005$ \\
$\alpha_{3}=\$ 1333$ & $\alpha_{4}=.15$ & $\rho=.935$ & $\sigma_{\nu}^{2}=.06$ \\
$B_{1}=\$ 531$ & $B_{2}=\$ 3202$ & $\sigma_{\varepsilon}^{2}=.008$ & \\
\hline Income and Payroll & Tax & TDA Rules & \\
\hline$\{.15, .28, .36, .396\}$ & tax brackets & $\tau_{w}=.10$ & penalty rate \\
$\{.05\}$ & state tax & $\xi=.25$ & contribution \\
$\tau_{s}=.062$ & OASDI tax & $L=\$ 10,500$ & limit \\
$y^{\text {max }}=\$ 76,200$ & max. taxable & & \\
\hline Earnings test & & \multicolumn{3}{l}{} \\
\hline$\tau^{0}=.50$ & $\bar{y}^{0}=\$ 10,080$ & \multicolumn{3}{l}{} \\
$\tau^{1}=.333$ & $\bar{y}^{1}=\$ 17,000$ & & \\
\hline \hline
\end{tabular}

\subsection{Benchmark Saving and Retirement}

As a benchmark, I first examine individuals' behavior when TDAs are not available.

Figure 3 shows life-cycle profiles for savings (CSAs only), consumption, employment,

and labor income, which are averages over a large number of simulations. In the

\footnotetext{
${ }^{17}$ Some $401(\mathrm{k})$ plans allow the owners to borrow against their vested balances up to a limit for specific reasons. They must pay the loan back with interest over a short period; otherwise a $10 \%$ early withdrawal penalty will apply in addition to income tax. Borrowing implies the loss of the taxdeferring advantage and the loan is repaid with after-tax income. IRA owners are subject to a fivetax-year waiting period before any withdrawal. There are exceptions to early withdrawal penalties but most do not apply to average tax payers. Such special events include permanent disability or death of the IRA owner, serious illness with expenses in excess of $7.5 \%$ of adjusted gross income, first-time home purchase with a lifetime limit of $\$ 10,000$, and medical insurance payment conditional on unemployment for more than twelve weeks.
} 
early phase of the life cycle, individuals need to rapidly build up a liquidity stock for precautionary and transaction reasons. Early consumption is depressed to some extent and closely tracks labor income, shifting upward as more resources become available. In the latter phase of the life cycle, effective impatience increases due to higher mortality risk. They are also assigning greater utility weight to leisure than they did earlier in life due to changing preferences. The consumption path hence slopes downward at this stage. A hump shape of life-cycle consumption emerges.
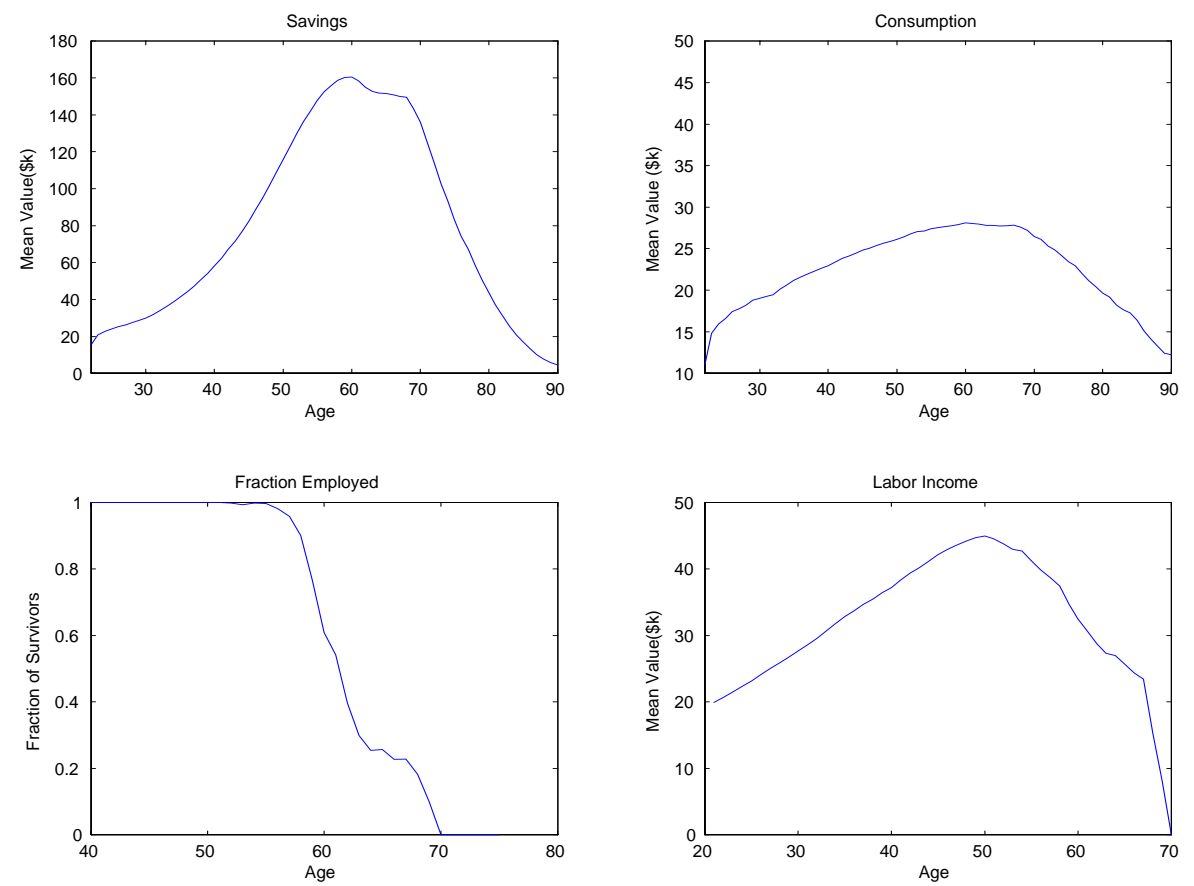

Figure 3: Benchmark Simulations - No TDAs

Once the buffer stock has reached a reasonable level, individuals start saving mainly for retirement. Individuals in the model start reducing labor supply on average in their late 50's. Wealth is decumulated to support consumption upon the transition from full-time to part-time work and the decumulation is more rapid after full retire- 
ment at age 70. Allowing for uncertain events during retirement in addition to the bequest motive would likely slow down the pace of wealth depletion. For instance, Rust (2005) shows that stochastic medical costs (and hence insurance coverage) have a large impact on faculty decisions regarding retirement, consumption, and wealth decumulation.

The timing of retirement is determined by several factors. First, changes in attitude towards work (i.e., $\eta$ ) make leisure significantly more appealing as agents age. Second, wealth accumulated is sufficient to support retirement consumption and bequests. Third, Social Security wealth facilitates the transition to lower labor supply. Although retirement and Social Security take-up are two discretionary decisions, they are not necessarily independent due to the existence of the earnings test. It is not optimal to claim Social Security while working full time if the earnings test will tax away all the benefits. The benchmark simulations show that quite a few individuals choose to switch to a part-time job in their 50's or 60's. The prevalence of part-time work echoes the findings by Ruhm (1990), who presents evidence from the Retirement History Longitudinal Survey "suggesting that partial retirement is both more prevalent and longer lasting than is generally believed" (p. 490). Fewer than two-fifth of the respondents retired directly from career jobs. Korczyk (2004) reports that 70 to 80 percent of older workers in surveys and public opinion polls expect to work at least part time in retirement. There apparently exists considerable discrepancy between the number of workers who desire to work part-time and the number who actually do so, due to various real world constraints. My model abstracts from these constraints 
and thus allows frictionless transitions from full-time to part-time jobs.

\subsection{Wealth Allocation between TDAs and CSAs}

This subsection describes life-cycle behaviors when both CSAs and TDAs are available. Figure 4 shows that individuals now allocate a substantial share of total wealth into TDAs. It demonstrates that there is to some degree a functional division between CSAs and TDAs, with the former serving mainly for liquidity and the latter for retirement. Savings are solely directed into CSAs in the beginning so as to rapidly establish a liquidity stock as a cushion against negative earnings shocks. ${ }^{18} \mathrm{CSA}$ balances increase with consumption because a bigger liquidity stock in CSAs is needed to accommodate a higher consumption. TDA contributions occur, up to the limit if desirable, when CSA savings have reached a reasonable level. Apparently, wealth accumulation through TDAs is not always feasible, particularly when individuals have no income available for TDA after giving priority to CSA buffer buildup. Alternatively, TDA contributions may hit the annual limit.

As illustrated in Section 1.2, sequencing savings between CSAs and TDAs is an optimal strategy in that forced early withdrawal from TDAs is costly. This does not necessarily imply that households require a liquidity buffer in CSAs that can absolutely cover all income shocks. TDAs may satisfy part of the need for precautionary savings since, after a period of time, the higher effective rate of return will more than

\footnotetext{
${ }^{18}$ This model abstracts from the case where employers match TDA contributions. Employer matching could make contributing early optimal, even with the need to build up liquidity savings in CSAs.
} 
offset the early withdrawal penalty. On the one hand, the bigger the liquidity buffer in CSAs, the less likely one is to suffer penalties or marginal disutility of reduced consumption in case of shocks. On the other hand, the earlier the TDA contributions, the larger effective tax subsidies can be harvested for retirement. The trade-off encourages households to accumulate a reasonable level in CSAs and then use TDA assets as a backup. When adverse shocks strike and the CSA balance falls short, households will partially liquidate TDA assets to inject liquidity into their CSA buffer.

Heterogeneity in preferences and income serves to shape the savings profile. Individuals with low income and low AIME attach higher weight to leisure and will choose to retire early. They exhaust CSA balances first and start tapping TDA assets at age 60 since TDAs are now equally liquid without penalty. Others, those with high earnings ability, may choose to continue to work and contribute to TDAs until age 70. Restricted by contribution limits, their labor income cannot be fully sheltered in TDAs and thus they continue to accumulate in CSAs.

\subsection{Effectiveness of Saving Incentives}

One important and widely debated issue is whether special retirement programs have generated new private savings. That is, to what extent are CSA and TDA savings substitutes? Engen, Gale, and Scholz (1994) and Gale and Scholz (1994) find little evidence that retirement programs raise private savings. On the contrary, Poterba, Venti, and Wise $(1995,1997)$ and Venti and Wise $(1986,1990,1995)$ argue that IRAs and 401(k)s do not crowd out other assets but instead constitute new savings. 


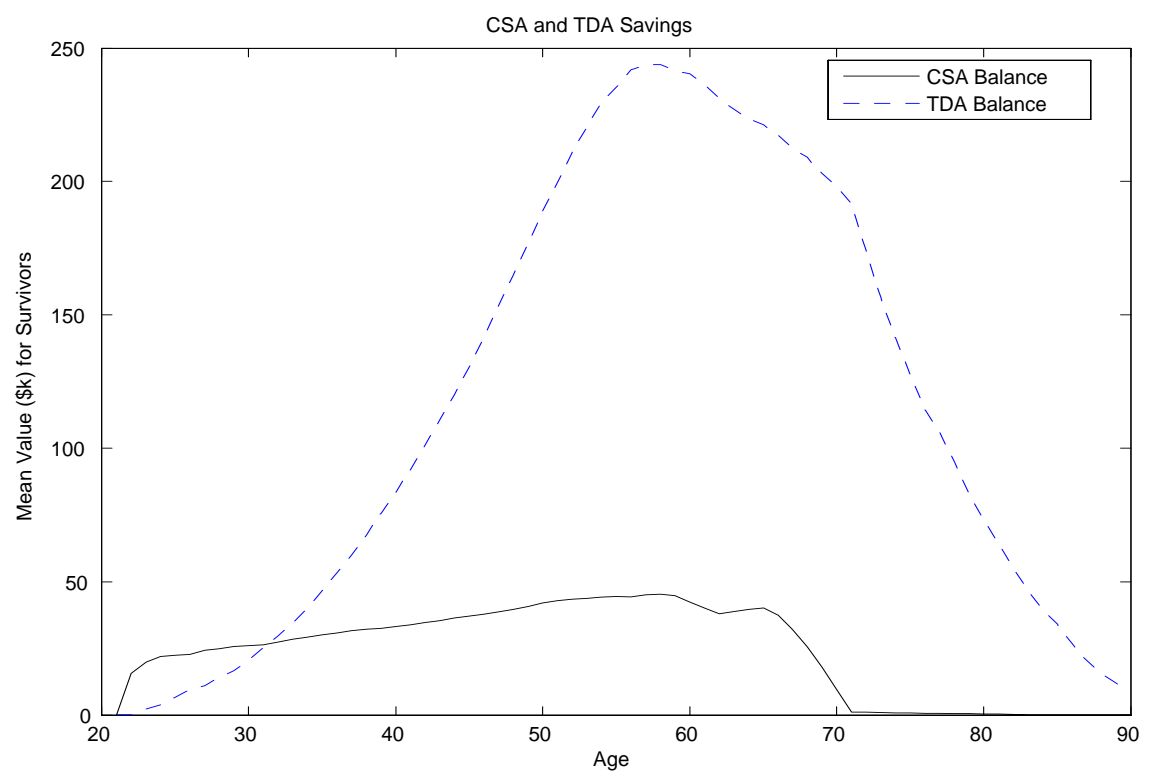

Figure 4: Asset Allocation between CSAs and TDAs

This quantitative life-cycle model sheds new light on this issue. First, the simulations clearly show that at least part of TDA savings are reshuffled from CSA savings. That is, the portion of CSA savings earmarked for retirement in the benchmark case are now shifted to TDAs. The simulated peak value of CSA assets on average is approximately $\$ 160,000$ in the benchmark case, while the average CSA balance never exceeds $\$ 50,000$ in the case with TDAs. Second, the tax incentives have limited effect on households in their early 20's, who have limited resources for long-term investment. The introduction of TDAs leads to little new savings in the very early stage of building up the CSA buffer. Third, in the TDA accumulation stage, the effective tax subsidy generates a substitution effect that induces more saving. At the same time, since TDA assets are accruing at a higher pre-tax rate, the income effect will depress savings. Whether TDAs lead to new saving depends on which effect dominates. Figure 5 
reveals that the substitution effect dominates between ages 20 and 45, as individuals sacrifice consumption to some extent in working years when TDAs are present. The difference between benchmark consumption and the path with TDAs constitutes new private savings in the early phase of the life cycle. In the later phase, TDAs facilitate a higher consumption path and encourage early retirement (see the next subsection for retirement behavior). The income effect thus dominates later since consumption and leisure are both normal goods.

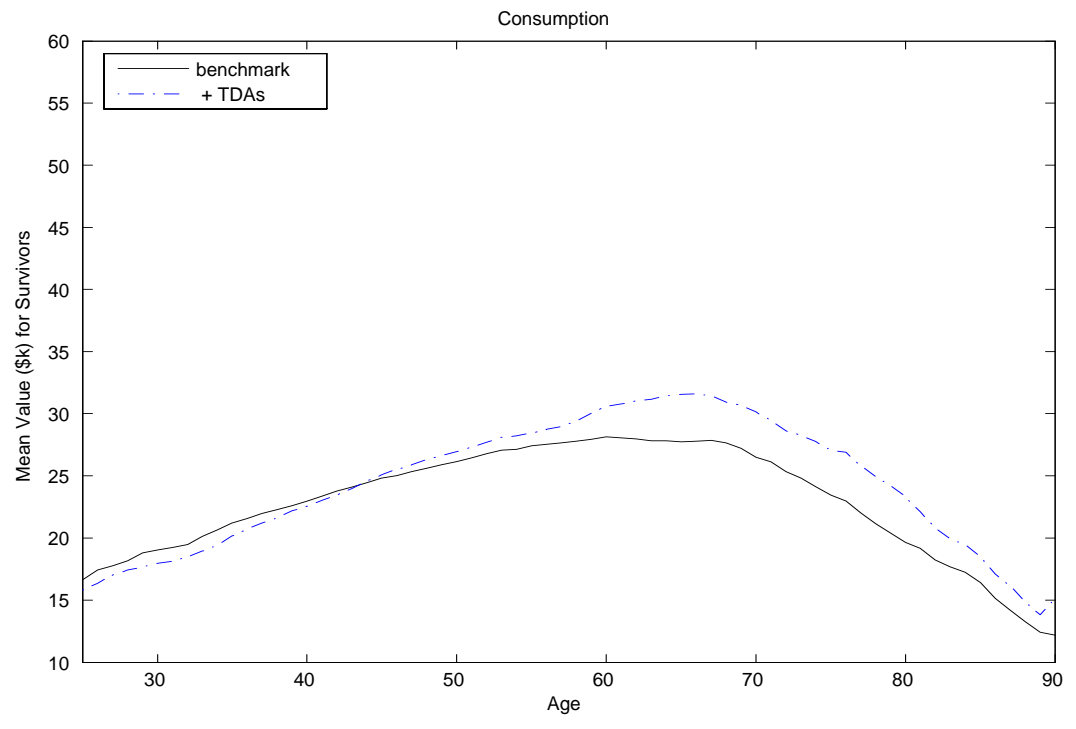

Figure 5: Comparison of Consumption

Some caution should be used when assessing the effectiveness of TDAs at stimulating new savings. This model is a partial equilibrium analysis, with the objective being to gain a deep understanding of the complex individual decisions. The model implicitly assumes that wages, rates of return, and tax rates are unchanged in spite of the introduction of TDAs. ${ }^{19}$ Government revenue loss due to the tax deduction on TDA

\footnotetext{
${ }^{19}$ The curse of dimensionality, due to the large number of state and choice variables, makes it
} 
contributions is not made up by imposing other taxes. Although government can partially recover these taxes upon TDA withdrawals, individuals may still receive net tax subsidies. The effectiveness of TDAs can be assessed only after subtracting tax loss from private savings. This loss is defined as the difference between tax revenue with TDAs and that without TDAs. Tax revenue includes the payroll tax on labor earnings, the progressive income tax on earnings, interest, TDA withdrawals, and income-adjusted Social Security benefits, the penalty on early TDA withdrawals, and the tax from the earnings test. The introduction of TDAs leads to a different life-cycle tax profile. Tax revenue prior to retirement is lower with TDAs due to the tax deferral associated with TDA contributions. Early retirement encouraged by TDAs (see the next subsection) implies further tax loss compared with the benchmark case since lower labor participation undercuts the tax base substantially. Tax revenue recovers considerably in one's 60's and 70's by virtue of the income tax on TDA withdrawals.

Table 4 reports the effectiveness of TDAs by age groups. Column 1 contains average contributions to CSAs in the benchmark case. Column 2 contains mean overall contributions when TDAs are available. The fraction of TDA contributions is reported in column 3. Mean tax loss is defined as above. Net new savings are calculated by netting out asset reshuffle and tax loss, specifically, defined as column 2 minus columns 1 and 4 , all divided by column 3. Clearly, tax-deferred programs produce private saving at the cost of government revenue. But they effectively induce substantial new national saving during the working years. A considerable fraction of these new savdifficult to extend the model to a general equilibrium framework while preserving the rich features. 
ings are utilized to finance early retirement, which is reflected in the apparently lower net new savings for ages 51-65 (8\%) and even negative net new savings (-11\%) for ages 61-65. These simple calculations suggest that the possibility of early retirement enhances the incentive to save through TDAs and that early retirement, facilitated by tax advantages in TDAs, shrinks the overall addition to national savings.

Table 4. Effectiveness of Tax Incentives

\begin{tabular}{lccccc}
\hline \hline & No TDAs & \multicolumn{4}{c}{ With TDAs } \\
Age & Overall $(\$)$ & Overall $(\$)$ & TDA $(\$)$ & Tax Loss $(\$)$ & New Savings $(\%)$ \\
\hline $21-30$ & 2,844 & 4,167 & 1,623 & 695 & 39.1 \\
$31-40$ & 2,062 & 4,997 & 4,430 & 1,372 & 35.5 \\
$41-50$ & 3,497 & 6,787 & 6,089 & 1,430 & 30.5 \\
$51-60$ & 2,298 & 3,602 & 3,977 & 991 & 8.1 \\
$61-65$ & -766 & $-1,563$ & $-2,350$ & $-1,052$ & -11.3 \\
$66-70$ & $-1,166$ & $-3,243$ & $-1,890$ & 195 & - \\
$71-80$ & $-3,115$ & $-4,977$ & $-3,984$ & $-1,622$ & - \\
$81-90$ & $-1,089$ & $-2,034$ & $-2,034$ & -596 & - \\
\hline \hline
\end{tabular}

Notes: 1. Negative values in column 4 represent tax gains. 2. Net new savings is defined as overall savings with

TDAs (col. 2) minus savings without TDAs (col. 1) and minus tax loss (col. 4), all divided by TDA savings (col. 3).

\subsection{Retirement Effect of TDAs}

The substitution effect, coming from the higher rate of return on TDAs, increases wealth accumulation and reduces consumption compared to the case without TDAs in the early phase of life cycle. One reason for this is that TDAs are utilized by individuals who are planning on earlier retirement. Leisure choice is a function of wealth, increasing with savings levels in both CSAs and TDAs, with the latter yielding a stronger impact. Figure 6 plots the employment status for survivors in the cohort and their financial resources to support retirement. Apparently, the higher pre-tax rate of return on TDAs implies a stronger income effect in the later phase of life cycle, 
which encourages more retirement. The fraction of survivors employed are lower in the TDA case than in the benchmark. Consequently, the drop in labor supply means less income. A considerable share of individuals now choose to claim Social Security earlier than otherwise since the earnings test is less likely to tax away income given lower levels of labor earnings. In short, the tax advantage of TDAs enables individuals to retire early. Social Security benefits serve as a complementary financial resource.

The finding that early retirement is encouraged by the introduction of TDAs should be given consideration in the process of policy formulation. Such early retirement does not necessarily add an immediate threat to the solvency of Social Security since, as modeled in this paper, the benefits are subject to approximately "actuarially fair" adjustment so that early claimers get lower benefits and delayed retirees receive higher benefits. However, as summarized by Gruber and Wise (2005), early retirement has substantial fiscal implications: it reduces tax revenue due to lower labor force participation and increases expenditure due to the increasing number of retirees.

\subsection{Cost-Benefit Analysis of TDAs}

Apparently, TDAs are welfare enhancing for households, since TDAs expand investment options and provide opportunities to accumulate wealth at pre-tax rate. As is shown in the top panel in Figure 7, the indirect value function for households with TDAs at all ages is above that without TDAs. TDAs at the same time carry cost in terms of tax loss from the fiscal perspective. For the purpose of cost-benefit analysis, I use the concept of equivalent variation (EV) to measure the welfare gain from TDAs 

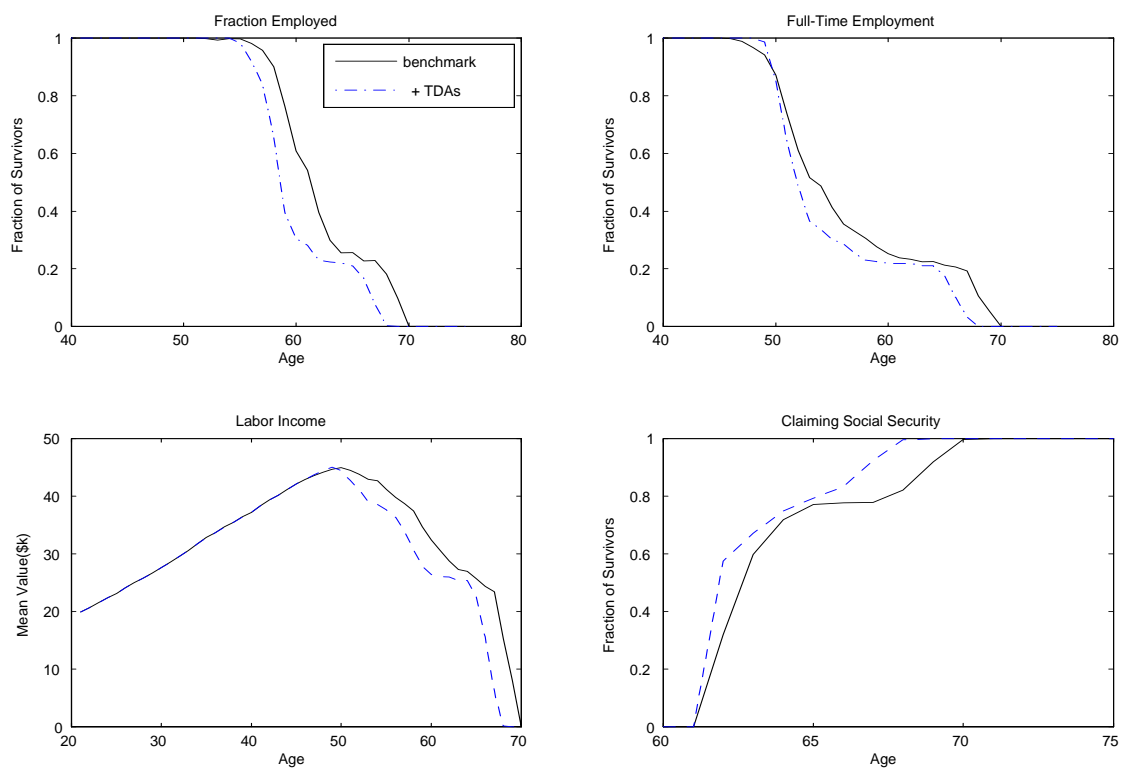

Figure 6: Retirement Effect of TDAs

for households. Specifically, the equivalent variation is numerically computed as the amount of extra CSA wealth required to make individuals without TDAs as well off as with TDAs in the expected utility terms. This benefit (EV) is compared with the fiscal cost, the present discounted value (PDV) of tax loss that is calculated as the difference between tax revenue with and without TDAs. The bottom panel of Figure 7 shows such cost-benefit analysis. In the early phase of the life-cycle, the fiscal cost outweighs the welfare gain. Put differently, there is room for Pareto improvement at this stage: both individuals and the government would be better off if the government gave individuals a lump sum transfer (in a magnitude smaller than the fiscal cost and bigger than EV) instead of the TDA options. This is because the transfer helps relax the budget constraint typically faced by workers in their 20's-30's. In the later phase of the life-cycle, the welfare benefit induced by TDAs exceeds the cost. 
This is because the tax deferral of TDAs offers effective means for retirement wealth accumulation. The fiscal cost in this phase is substantially lower, thanks to the tax recovery upon TDA withdrawals.
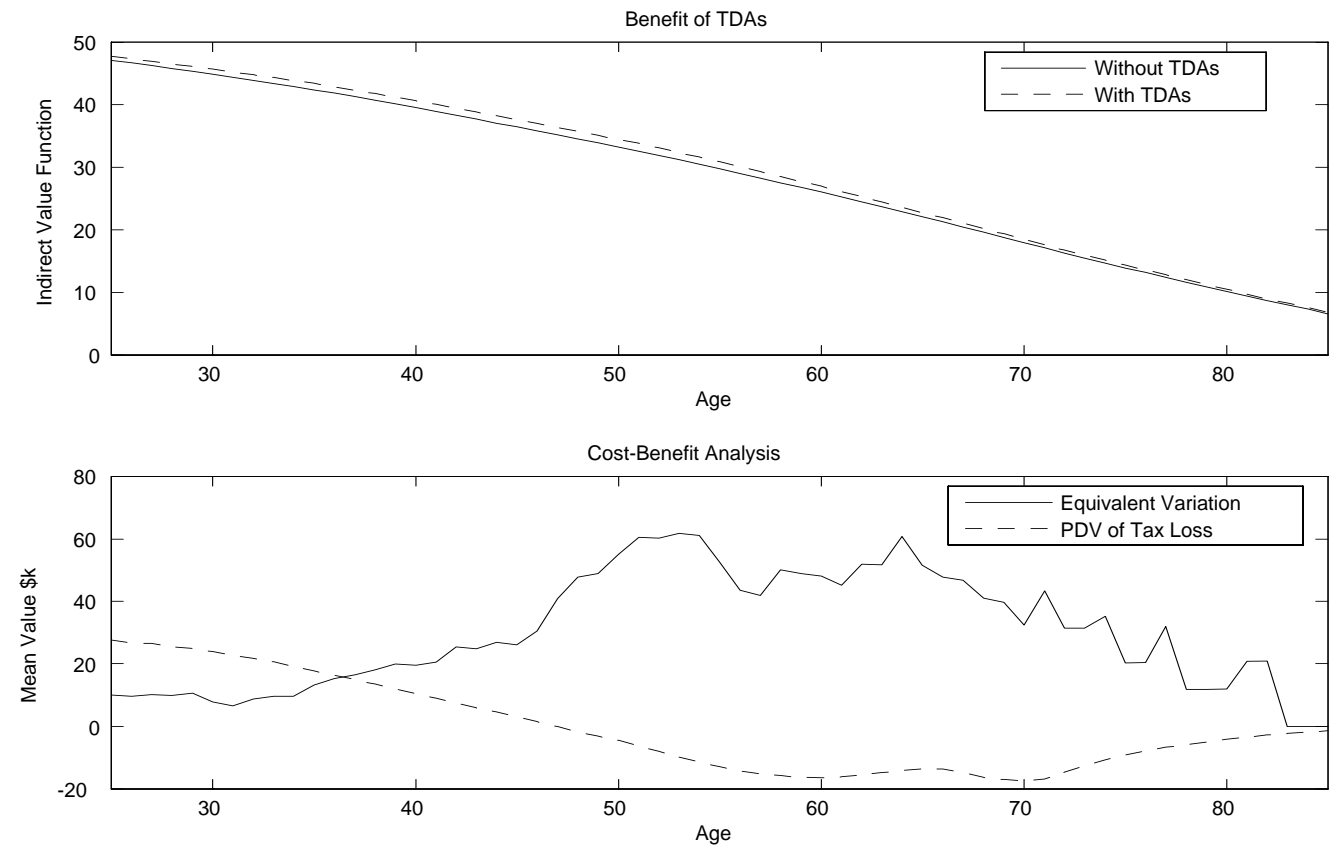

Figure 7: Welfare and Cost-Benefit Analysis

\section{Alternative Policies and Heterogeneity}

\subsection{Alternative Policies and Impact of TDAs}

This section presents the impact of TDAs on saving and retirement behavior for different policy scenarios. Table 5 reports the results from assuming alternative policies. First, assuming mandatory retirement and Social Security take-up at age 65 (experiment 2), individuals in the model would save less in terms of dollar value than in the 
case of flexible retirement choice. This implies higher consumption prior to retirement since mandatory retirement yields higher cumulative lifetime earnings before age 65 . On the other hand, the fraction of TDA savings that represent new savings is now substantially higher than in experiment $1 .^{20}$ This is because individuals contemplating early retirement in mind would shift more savings from CSAs to TDAs. This finding shows that the possibility of early retirement encourages tax-deferred savings and national savings compared with the case of mandatory retirement, but with a larger share of reshuffling of savings from CSAs to TDAs.

Second, an experiment is carried out to study how the bequest motive alters saving profiles. Kotlikoff and Summers (1981), Hurd and Smith (1999), Dynan, Skinner and Zeldes (1996), and De Nardi (2004) show that the bequest motive is an important factor in explaining the upper tail of the wealth distribution. This experiment assumes higher utility from bequest $(\kappa=.4)$ as opposed to the modest bequest motive assumed in experiment $1(\kappa=.2)$. Not surprisingly, individuals would contribute more to TDAs by reshuffling a larger part of CSA wealth compared with experiment 1 , thus yielding a lower share of new savings in TDAs.

Third, one may be concerned that a certain degree of employer intervention is embedded in 401(k)s, which may significantly restrict individuals' voluntary choices. I thus narrow my definition of TDAs to include IRAs only, by decreasing the annual TDA contribution limit to $L=\$ 4,000$, which is the total allowable amount in 2005 for annual IRA contribution. A larger fraction of individuals in this case are restricted

\footnotetext{
${ }^{20}$ The assessment of new saving in experiment 2 is compared with a benchmark with mandatory retirement at 65 but no TDAs.
} 
by the contribution limits. Nevertheless, IRAs are still an effective means to solicit new savings and to support early retirement.

Fourth, holding the contribution limit constant, a higher withdrawal penalty $\left(\tau_{w}=\right.$ .30) forces individuals to make TDA investments more conservatively. The role of TDAs as a backup for emergency liquidity is undercut by the high penalty. Put differently, a larger CSA buffer is necessary before saving in TDAs is optimal.

Table 5. Alternative Policies and the Impact of TDAs

\begin{tabular}{l|ccc|ccc}
\hline \hline & \multicolumn{3}{|c|}{ Ages 21-65 savings(\$k) } & \multicolumn{3}{c}{ Ages 21-90 savings(\$k) } \\
\cline { 2 - 7 } & Overall & TDAs & $\%$ New & Overall & TDAs & $\%$ New \\
\hline 1. Bench. + TDAs & 187.2 & 148.9 & 30.3 & 101.6 & 79.7 & 35.3 \\
2. Mandatory at 65 & 184.3 & 137.3 & 43.1 & 86.4 & 64.2 & 65.2 \\
3. Bequest $(\kappa=.4)$ & 189.8 & 150.9 & 29.5 & 104.3 & 82.1 & 34.7 \\
4. $L=\$ 4,000$ & 170.4 & 127.0 & 27.5 & 93.1 & 67.6 & 34.4 \\
5. $\tau_{w}=.30$ & 181.5 & 142.1 & 29.0 & 96.3 & 72.2 & 35.7 \\
\hline \hline
\end{tabular}

\subsection{Heterogeneity and impact of TDAs}

To this point I have considered only how TDAs affect the mean behavior of households. Undoubtedly, there is tremendous heterogeneity among individuals. Table 6 and Figure 8 present findings along this line. First, TDAs have differential impacts between high- and low-income groups. TDAs are more effective in stimulating new savings for the top quintile than for the bottom quintile, with the fraction of new savings being $51.7 \%$ and $1.8 \%$, respectively. This is in line with the findings of Venti and Wise (1991 and 1992) and Gale and Scholz (1994), who observe that households with more wealth and higher income tend to make more contributions to IRAs. The existence of TDAs generates a strong retirement effect on the rich despite the assumption that high income earners (proxied by AIME) place a lower preference weight on 
leisure compared with the poor. Many of them switch to part-time work and elect to claim Social Security earlier than otherwise (Figure 8). The behavior of the poor, on the other hand, is less altered by the introduction of TDAs for several reasons. First, the poor have few resources available to take advantage of TDAs, and they derive less benefit from tax deferral because they face lower marginal tax rates. Second, agents with low earnings attach more weight to the disutility of work, so they tend to retire early even in the absence of TDAs. Third, poor agents tend to claim Social Security early even absent TDAs, so there is no impact of TDAs on the claiming decision for these workers.

Table 6. Heterogeneity and the Impact of TDAs

\begin{tabular}{lcccccc}
\hline \hline & \multicolumn{2}{c}{ Ages 21-65 Savings(\$k) } & \multicolumn{3}{c}{ Ages 21-90 Savings $(\$ \mathrm{k})$} \\
\cline { 2 - 7 } & Overall & TDAs & \% New & Overall & TDAs & $\%$ New \\
\hline 1. Bot 20\% & 52.8 & 26.9 & -5.0 & 35.3 & 14.3 & 1.8 \\
2. Top 20\% & 390.2 & 278.3 & 45.0 & 187.9 & 140.9 & 51.7 \\
3. Impatience & 23.0 & 1.2 & -86.5 & 22.9 & 1.2 & -88.9 \\
4. Mortality & 18.3 & 2.9 & -81.6 & 15.0 & 2.7 & -88.9 \\
\hline \hline
\end{tabular}

These results shed new light on the relationship between Social Security and retirement. Rust and Phelan (1997) show that a drop in employment at age 62 is an optimal response for liquidity constrained individuals since 62 is the earliest age for Social Security eligibility. The retirement and claiming decisions of the bottom quintile in this model confirm their findings. As for the rich, they will also retire early if they have accumulated sufficient wealth, and they will optimally claim Social Security to complement retirement financing, even though they do not face a cash shortage. This model predicts that retirement can be encouraged by a public scheme - the creation of TDAs. ${ }^{21}$

\footnotetext{
${ }^{21}$ This loosely echoes Feldstein (1974) who shows that Social Security induces retirement.
} 

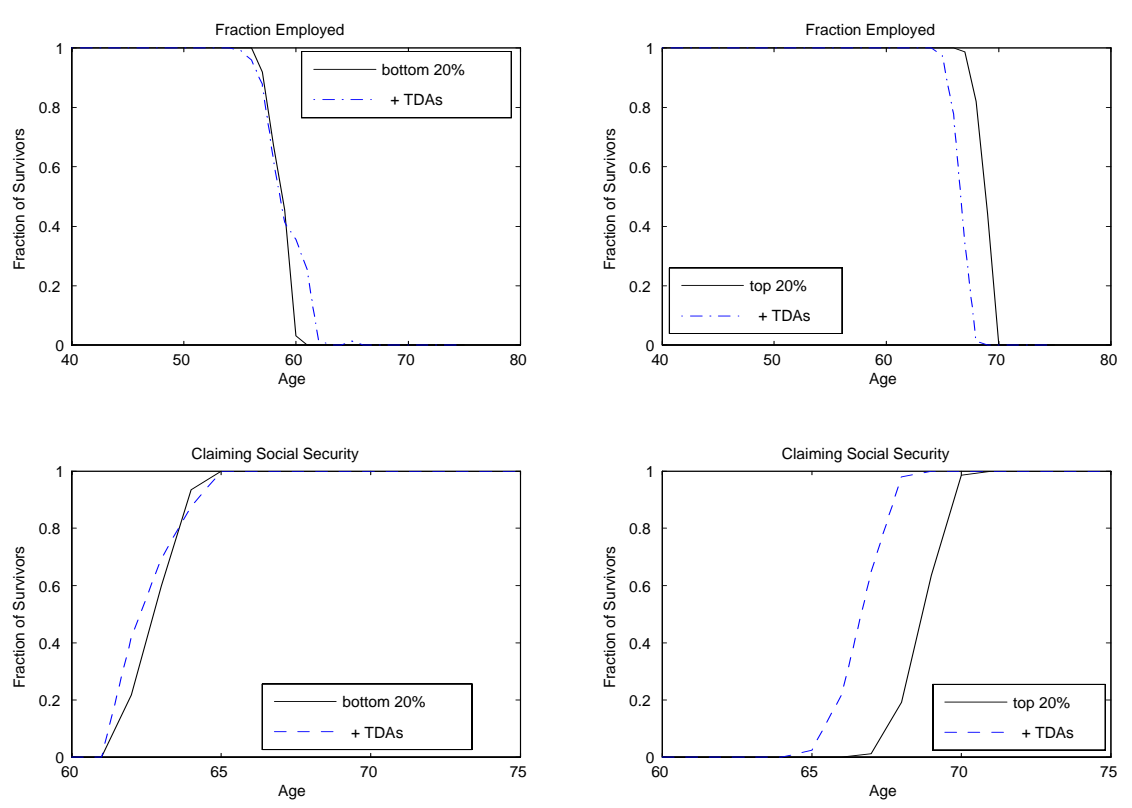

Figure 8: TDAs and Income Heterogeneity

Second, I explore how savings and retirement behavior would change in the case of myopia, which is motivated by Feldstein (1985), who argues that "some individuals lack the foresight to save for their retirement years (p.303)". Complete myopia would imply that individuals do not expect to retire and thus do no saving. This would imply that TDAs are totally irrelevant to them. I thus introduce the more relevant case of partial myopia, in which individuals give little weight to future utility, following Feldstein. But I assume they correctly estimate future social security benefits, in order to isolate the impact of TDAs. Here a higher subjective discount rate $(\beta=.9)$ is used to reflect such impatience. Impatient individuals usually claim Social Security as their main financial source at 62 . TDAs fail to solicit new savings from this group. Not surprisingly, the net addition to national savings is negative since the income effect dominates over the whole lifetime. 
Third, the exercise is redone for the scenario in which mortality risk and average earnings are strongly negatively related. Duggan, Singleton and Song (2005) suggests that the mortality rate for those in top decile of AIME at age 62 is three times lower than for those in lowest decile. This will affect the optimal time to claim Social Security. The simulations for the group of individuals with a high mortality rate and low AIME reveal that they tend to retire early and claim Social Security at the earliest eligible age, with or without TDAs. Similar to the case of impatience, TDAs mainly boost consumption for groups with high mortality risk, yielding negative new savings.

\section{Concluding Remarks}

This paper combines the assessment of special savings plans with the study of retirement behavior. I develop a quantitative and realistically calibrated model to solve for optimal consumption/saving and leisure decisions of finitely lived individuals who face mortality risk and stochastic earnings. Individuals are assumed to save for liquidity reasons, for retirement and for bequests. They hold assets in conventional savings and tax-deferred accounts. They also make endogenous labor supply and retirement choices and a separate decision on the timing of Social Security take-up.

The simulations reveal that there is a functional division between CSAs and TDAs, with the former serving mainly for liquidity and the latter for retirement and bequests. The stronger the incentive to retire early, the more attractive is the TDA option. 
Individuals who are contemplating early retirement tend to hold more savings in terms of dollar value, shift a greater fraction of assets from CSAs to TDAs and have a lower share of new net savings in TDAs than otherwise. The effectiveness of savings incentives is also strengthened by the voluntary bequest motive.

There is tremendous heterogeneity with regard to the utilization of TDAs, retirement decisions, and Social Security claiming. The tax incentives are generally most effective at stimulating new savings for the middle and upper income groups. The introduction of TDAs appears to exert a bigger impact on their life-cycle behavior. The higher rate of return on TDAs facilitates wealth accumulation, which consequently and perhaps unintentionally encourages early retirement. Impatient and low-income individuals tend to retire and claim Social Security early with or without TDAs. They contribute much less to TDAs both because they face lower marginal tax rates and because they have limited resources with which to take advantage of TDAs. For them, the income effect dominates and TDAs fail to induce new savings. The finding that early retirement is associated with TDAs should be given consideration in the process of policy formulation. As summarized by Gruber and Wise (2005), early retirement has substantial fiscal implications, since it reduces tax revenue due to lower labor force participation and increases expenditure due to the increasing number of retirees, despite the approximately "actuarially fair" adjustment of Social Security benefits.

There is no doubt about the increasing importance of tax deferred programs with regard to national savings and individual retirement wealth security. They deserve further study in various aspects. First, the newly induced savings will likely alter 
the level of capital stock as well as factor prices. A general equilibrium model is a natural step to quantify this second-round effect. Second, along with their popularity, 401(k) plans increasingly offer loans. It is worth exploring the effects of the universal availability of pension loans on asset location choice and retirement wealth security. These are on the agenda for future research. 


\section{Appendix A. The Derivation of Heuristic Findings}

To derive some heuristic findings, I assume a flat and constant income tax at rate $\tau$, maintaining the assumptions that TDAs accrue tax free and are subject to early withdrawal penalty. Allowing for a progressive tax system will strengthen the analysis in the text. The stripped down version of the utility maximization problem and the dynamic budget constraints and contribution limits can be written as follows. ${ }^{22}$

$$
\begin{aligned}
& \max _{c, l, x, z^{d}} E_{t} \sum_{t=0}^{T} \beta^{t}\left[\Psi_{t} u\left(c_{t}, l_{t}\right)+\left(1-\Psi_{t}\right) \Gamma\left(w_{t}\right)\right] \\
& \text { s.t. } \\
& \mu_{t}^{B} \quad: \quad a_{t+1}=[1+(1-\tau) r] a_{t}+y\left(l_{t}\right)+b \\
&-\left(1-\lambda_{t} \tau_{w}\right)\left[q_{t+1}-(1+r) q_{t}\right]-c_{t} \\
& \mu_{t}^{L} \quad: \quad L \geqslant q_{t+1}-(1+r) q_{t} \\
& \mu_{t}^{a} \quad: \quad a_{t} \geqslant 0 \\
& \mu_{t}^{q} \quad: \quad q_{t} \geqslant 0
\end{aligned}
$$

where $\left.w_{t}=[1+(1-\tau) r)\right] a_{t}+(1+r) q_{t}$ is the terminal wealth bequeathed; and $\mu^{\prime} s$ in front of the constraints are the corresponding Lagrange multipliers.

\section{A.1 Consumption}

Plugging the expression for $c_{t}$ defined in the dynamic budget constraint into the objective function and taking first order conditions w.r.t. $a_{t+1}$ and $q_{t+1}$, respectively,

\footnotetext{
${ }^{22}$ With slight abuse of notation, $y\left(l_{t}\right)$ here indicates disposable income net of income and payroll taxes.
} 
yields

$$
\begin{aligned}
a_{t+1}: u_{c}^{\prime}\left(c_{t}, l_{t}\right) & =\beta[1+(1-\tau) r] E_{t}\left[\psi_{t+1} u_{c}^{\prime}\left(c_{t+1}, l_{t+1}\right)\right. \\
& \left.+\left(1-\psi_{t+1}\right) \Gamma^{\prime}\left(w_{t+1}\right)\right]+E_{t} \mu_{t+1}^{a} \\
q_{t+1}: \quad\left(1-\lambda_{t} \tau_{w}\right) & u_{c}^{\prime}\left(c_{t}, l_{t}\right)=\beta(1+r) E_{t}\left[\left(1-\lambda_{t+1} \tau_{w}\right) \psi_{t+1} u_{c}^{\prime}\left(c_{t+1}, l_{t+1}\right)\right. \\
& \left.+\left(1-\psi_{t+1}\right) \Gamma^{\prime}\left(w_{t+1}\right)\right]-\mu_{t}^{L}+(1+r) E_{t} \mu_{t+1}^{L}+E_{t} \mu_{t+1}^{q}
\end{aligned}
$$

Combining the above two equations yields

$$
\begin{aligned}
& \beta[1+(1-\tau) r] E_{t}\left[\psi_{t+1} u_{c}^{\prime}\left(c_{t+1}, l_{t+1}\right)+\left(1-\psi_{t+1}\right) \Gamma^{\prime}\left(w_{t+1}\right)\right]+E_{t} \mu_{t+1}^{a} \\
= & \frac{\beta(1+r)}{1-\lambda_{t} \tau_{w}} E_{t}\left[\left(1-\lambda_{t+1} \tau_{w}\right) \psi_{t+1} u_{c}^{\prime}\left(c_{t+1}, l_{t+1}\right)+\left(1-\psi_{t+1}\right) \Gamma^{\prime}\left(w_{t+1}\right)\right] \\
& \frac{1}{1-\lambda_{t} \tau_{w}}\left[-\mu_{t}^{L}+(1+r) E_{t} \mu_{t+1}^{L}+E_{t} \mu_{t+1}^{q}\right]
\end{aligned}
$$

This equation implies that an optimal interior asset allocation between CSAs and TDAs is reached when a dollar contribution to CSAs or TDAs brings the same level of marginal expected utility (otherwise a corner solution emerges, so that contributions will be made in only one type of account). An interesting special case arises when an individual contributes to TDAs at $t$ (hence $\lambda_{t}=0$ ) and future withdrawals are not subject to penalty (i.e. $\lambda_{t+1}=0$ with probability one). Then the above equation is reduced to the following. See text for the interpretation.

$$
\begin{aligned}
& \beta \tau r E_{t}\left[\psi_{t+1} u_{c}^{\prime}\left(c_{t+1}, l_{t+1}\right)+\left(1-\psi_{t+1}\right) \Gamma^{\prime}\left(w_{t+1}\right)\right] \\
= & E_{t} \mu_{t+1}^{a}+\mu_{t}^{L}-(1+r) E_{t} \mu_{t+1}^{L}-E_{t} \mu_{t+1}^{q}
\end{aligned}
$$




\section{A.2 Saving Rules}

Let $V\left(\Lambda_{t}\right)$ denote the indirect utility realized at $t$ given the beginning-of-period states $\Lambda_{t}=\left(t, a_{t}, e_{t}, q_{t}, \varepsilon_{t}, z_{t}^{s}\right)$. Taking derivatives to $V\left(\Lambda_{t}\right)$ w.r.t. $a_{t}$ and $q_{t}$, respectively, and applying the Envelope Theorem produces the following equations.

$$
\begin{aligned}
V_{a}^{\prime}\left(\Lambda_{t}\right) & =[1+r(1-\tau)]\left[\mu_{t}^{B}+\beta\left(1-\psi_{t}\right) \Gamma^{\prime}\left(w_{t}\right)\right]+\mu_{t}^{a} \\
V_{q}^{\prime}\left(\Lambda_{t}\right) & =(1+r)\left[\mu_{t}^{B}\left(1-\lambda_{t} \tau_{w}\right)+\beta\left(1-\psi_{t}\right) \Gamma^{\prime}\left(w_{t}\right)+\mu_{t}^{L}\right]+\mu_{t}^{q}
\end{aligned}
$$

Shifting these equations forward by one year gives the expected marginal value of savings in the two accounts, respectively.

$$
\begin{aligned}
E_{t} V_{a}^{\prime}\left(\Lambda_{t+1}\right)= & {[1+r(1-\tau)] E_{t}\left[\mu_{t+1}^{B}+\beta\left(1-\psi_{t+1}\right) \Gamma^{\prime}\left(w_{t+1}\right)\right]+E_{t} \mu_{t+1}^{a} } \\
E_{t} V_{q}^{\prime}\left(\Lambda_{t+1}\right)= & (1+r) E_{t}\left[\mu_{t+1}^{B}\left(1-\lambda_{t+1} \tau_{w}\right)\right. \\
& \left.+\beta\left(1-\psi_{t+1}\right) \Gamma^{\prime}\left(w_{t+1}\right)+\mu_{t+1}^{L}\right]+E_{t} \mu_{t+1}^{q}
\end{aligned}
$$

\section{A.3 Retirement Effect of TDAs}

Taking first order condition to the utility maximization problem w.r.t. leisure $l_{t}$ yields

$$
u_{l}^{\prime}\left(c_{t}, l_{t}\right)=-u_{c}^{\prime}\left(c_{t}, l_{t}\right) y^{\prime}\left(l_{t}\right)
$$

where $y^{\prime}\left(l_{t}\right)<0$. This equation facilitates implementing comparative statics on optimal labor supply with respect to $a_{t}$ and $q_{t}$. Applying Implicit Function Theorem yields

$$
\begin{aligned}
\frac{\partial l_{t}}{\partial a_{t}} & =-\frac{[1+(1-\tau) r]\left[u_{l c}^{\prime \prime}\left(c_{t}, l_{t}\right)+u_{c c}^{\prime \prime}\left(c_{t}, l_{t}\right) y^{\prime}\left(l_{t}\right)\right]}{u_{c}^{\prime}\left(c_{t}, l_{t}\right) y^{\prime \prime}\left(l_{t}\right)} \\
\frac{\partial l_{t}}{\partial q_{t}} & =-\frac{(1+r)\left(1-\lambda_{t} \tau_{w}\right)\left[u_{l c}^{\prime \prime}\left(c_{t}, l_{t}\right)+u_{c c}^{\prime \prime}\left(c_{t}, l_{t}\right) y^{\prime}\left(l_{t}\right)\right]}{u_{c}^{\prime}\left(c_{t}, l_{t}\right) y^{\prime \prime}\left(l_{t}\right)}
\end{aligned}
$$


It is straightforward to show that $u_{l c}^{\prime \prime}=0$ and $u_{c c}^{\prime \prime}<0$ given the period utility and bequest functions and $\gamma>1$. Also, it is reasonable to assume that $y^{\prime \prime}\left(l_{t}\right)>0$, which means that the opportunity cost of leisure in terms of foregone wages is declining with leisure. Thus,

$$
\begin{aligned}
\frac{\partial l_{t}}{\partial a_{t}} & >0 \\
\frac{\partial l_{t}}{\partial q_{t}} & >0
\end{aligned}
$$

and the comparison of them further reveals that

$$
\frac{\partial l_{t}}{\partial q_{t}}>\frac{\partial l_{t}}{\partial a_{t}}
$$

which is particularly true when withdrawals take place at age $t \geqslant t^{f}$ (i.e. $\lambda_{t}=0$ ). 


\section{Appendix B. The Solution Method}

Given the large number of state and choice variables, numerical method is used to solve the model. The computation begins by discretizing the space of the continuous state variables, i.e., CSA assets, $a$, TDA assets, $q$, and AIME, $e$. The discretization yields denser grid points at lower values and coarser points towards the upper end, which is to accommodate the potential nonlinearity and sensitivities in decision rules.

I first solve the trivial maximization problem for age $T$, the last period, where individuals simply divide wealth between consumption and bequest. The value function is derived as $V\left(\Lambda_{T}\right)$. Then the computation moves backward to solve for the optimal decisions and the value function for age $T-1$. If the realized assets do not lie on the grids on which the expected value function is defined, linear interpolations are implemented. This backward induction continues until the starting age is reached. Along the process, the optimal decisions are recorded for all feasible realizations of random variables (earnings and mortality) given initial states. Policy functions are thus defined as $a_{t+1}=f\left(t, a_{t}, e_{t}, q_{t}, \varepsilon_{t}, z_{t}^{s}\right)$, and $q_{t+1}=f\left(t, a_{t}, e_{t}, q_{t}, \varepsilon_{t}, z_{t}^{s}\right)$, for $t=20, \ldots, T$. The fully-loaded model requires tremendous computational resources, including those granted by the Pittsburgh Supercomputer Center. The computation is run in parallel on a large number of computers, using the Message Passing Interface (MPI) standard. In each decision-making age, the up-to-date value functions and a subset of state variables are passed on to each parallel processor for evaluation. The newly derived value functions and decision rules are gathered and to be collectively shared next period. 
With optimal decision rules derived, large scale simulations are carried out to generate life-cycle profiles of earnings, savings, labor supply, and Social Security. Simulations start with age 21 when individuals are endowed with no assets. They make optimal choices based on policy and value functions derived above. Values of random variables are generated by Monte Carlo method. Simulations move forward until end of the life cycle. 


\section{References}

1. Auerbach, Alan and Laurence J. Kotlikoff. 1987. Dynamic Fiscal Policy, Cambridge University Press.

2. Autor, David H. and Mark G. Duggan. 2003. "The Rise in the Disability Rolls and the Decline in Unemployment." The Quarterly Journal of Economics, February.

3. Benjamin, Daniel J. 2003. "Does 401(k) eligibility increase saving?: Evidence from propensity score subclassification." Journal of Public Economics, pp. 12591290.

4. Blau, D. M. and D. B. Gilleskie, 2003. "The Role of Retiree Health Insurance in the Employment Behavior of Older Men," NBER working paper 10100.

5. Burman, Leonard, William G. Gale and David Weiner, 2001. "The Taxation of Retirement Saving: Choosing Between Front-Loaded and Back-Loaded Options", Mimeo, The Brookings Institution, May 31.

6. Burtless, Gary. 1986. "Social Security, Unanticipated Benefit Increases, and the Timing of Retirement." The Review of Economic Studies. Vol. 53, No. 5, pp. 781-805.

7. Carroll, Christopher D. 1992. "The Buffer-Stock Theory of Saving: Some Macroeconomic Evidence," Brookings Papers on Economic Activity, 1992(2), $61-156$.

8. Carroll, Christopher. 2001. "A Theory of the Consumption Function, With and Without Liquidity Constraints," Journal of Economic Perspectives, 15, 23-45.

9. Dammon, Robert M., Chester S. Spatt and Harold H. Zhang. 2004. "Optimal Asset Location and Allocation with Taxable and Tax-Deferred Investing," The Journal of Finance, Vol. LIX, No. 3.

10. Deaton, Augus, 1991. "Saving and Liquidity Constraints," Econometrica, Vol. 59, Issue 5 (Sep.), 1221-1248.

11. De Nardi, Mariacristina. 2004. "Wealth Inequality and Intergenerational Links", Review of Economic Studies, 71, 743-768.

12. Duggan, Mark, Perry Singleton, and Jae Song. 2005. "Aching to Retire? The Rise in the Full Retirement Age and its Impact on the Disability Rolls". Mimeo, University of Maryland.

13. Dynan, Karen, Jonathan Skinner, and Stephen Zeldes. 2000. "Do the Rich Save More?" NBER Working Paper No. 7906. 
14. Engen, E. M. and William G.Gale. 1993. "IRAs and Saving in a Stochastic Life-Cycle Model," Mimeo, University of California, Los Angeles.

15. Engen, E. M., William G.Gale, and John Karl Scholz. 1994. "Do Saving Incentives Work?" Brookings Papers on Economic Activity, 1994:1, 85-180.

16. Farhi, Emmanuel and Stavros Panageas. 2005. "Saving and Investing for Early Retirement: A Theoretical Analysis". USC FBE Macroeconomics and International Finance Workshop.

17. Feldstein, Martin. 1974. "Social Security, Induced Retirement, and Aggregate Capital Accumulation." Journal of Political Economy, Sept./Oct. 82(5), pp. 905-26.

18. Feldstein, Martin. 1985. "The Optimal Level of Social Security Benefits." The Quarterly Journal of Economics, Vol. 100, No.2 (May), 303-320.

19. Gale, William G. 1998. "The Effects of Pensions on Households Wealth: A Reevaluation of Theory and Evidence." Journal of Political Economy, August, 106(4), pp.706-23.

20. Gale, William G. and John Karl Scholz. 1994. "IRAs and Household Saving." American Economic Review, 84, 1233-60.

21. Gruber, Jonathan and David Wise. 2005. "Social Security Programs and Retirement Around the World: Fiscal Implications, Introduction and Summary." NBER Working Paper No. 11290.

22. Gustman, Alan L. and Thomas L. Steinmeier. 1986. "A Structural Retirement Model", Econometrica, 54(3), 555-584.

23. Gustman, Alan L. and Thomas L. Steinmeier. 1999. "Effects of Pensions on Savings: Analysis with Data from the Health and Retirement Study." CarnegieRochester Conference Series on Public Policy, June, 50(99), pp.271-324.

24. Gustman, Alan L. and Thomas L. Steinmeier. 2003. "Retirement Effects of Proposals by the President's Commission to Strengthen Social Security." NBER Working Paper w10030.

25. Hall, Robert E. 1988. "Intertemporal Substitution in Consumption." The Journal of Political Economy, Vol. 96, No.2, pp. 339-357.

26. Heathcote, Jonathan, Kjetil Storesletten, and Giovanni L Violante. 2004. "The Cross-Sectional Implications of Rising Wage Inequality in the United States." Center for Economic Policy Research Discussion Paper No. 4296.

27. Huang, Jennifer. 2003. "Portfolio Decisions with Taxable and Tax-Deferred Accounts: A Tax-Arbitrage Approach." Manuscript, University of Texas. 
28. Hubbard, R. Glenn, and Jonathan S. Skinner. 1996. "Assessing the Effectiveness of Saving Incentives." The Journal of Economic Perspectives, Vol. 10, No. 4 (Autumn), 73-90.

29. Hubbard, R. Glenn and Kenneth L. Judd. 1987. "Social Security and Individual Welfare: Precautionary Saving, Borrowing Constraints, and the Payroll Tax." American Economic Review, 77(4): 630-646.

30. Hurd, Michael D. 1989. "Mortality Risk and Bequests." Econometrica, July, 57(4), pp. 779-813.

31. Hurd, Michael D. and Monika Reti. 2001. "The Effects of Large Capital Gains on Work and Consumption: Evidence from Four Waves of the HRS." Final Report prepared for the US Department of Labor under contract J-9-P-7-0045.

32. Hurd, Michael D. and J. P. Smith. 1999. "Anticipated and Actual Bequests." NBER Working Paper No. 7380.

33. Imbens, Guido W., Donald B. Rubin and Bruce Sacerdote. 2001. "Estimating the Effect of Unearned Income on Labor Earnings, Savings, and Consumption: Evidence from a Survey of Lottery Players." The American Economic Review, Vol. 91, No. 4 (Sep.), 778-794.

34. Imrohoroglu, Ayse, Selahattin Imrohoroglu and Douglas H. Joines. 1998. "The Effect of Tax-Favored Retirement Accounts on Capital Accumulation." The American Economic Review, Vol. 88, No. 4. 749-768.

35. Korczyk, Sophie M. 2004. "Is Early Retirement Ending?" The AARP Public Policy Institute, \#2004-10

36. Kotlikoff, L. J. and L. H. Summers. 1981. "The Role of Intergenerational Transfers in Aggregate Capital Accumulation." Journal of Political Economy, 89(4), 706-732.

37. Krueger, Alan B. and Jorn-Steffen Pischke. 1992. "The Effect of Social Security on Labor Supply: A Cohort Analysis of the Notch Generation." Journal of Labor Economics, Vol. 10, No.4 (Oct.), 412-437.

38. Kydland, Finn E., and Edward C. Prescott. 1982. "Time to Build and Aggregate Fluctuations." Econometrica, Vol. 50, No. 6, pp. 1345-1370.

39. Papke, Leslie, 1995. "Does 401(k) Introduction Affect Defined Benefit Plans." National Tax Association Proceedings, 173-77.

40. Penner, Rudolph G., Pamela Perun, and C. Eugene Steuerle. 2002. "Legal and Institutional Impediments to Partial Retirement and Part-Time Work by Older Workers." The Urban Institute. 
41. Poterba, James M. and Andrew Samwick. 2003. "Taxation and Household Portfolio Composition: U.S. Evidence from the 1980s and 1990s." Journal of Public Economics, 87, 5-38.

42. Poterba, James M., Steven F. Venti, and David A. Wise. 1995. "Do 401(k) Contributions Crowd Out Other Personal Saving." Journal of Public Economics, 58, $1-32$

43. Poterba, James M., Steven F. Venti, and David A. Wise. 1996. "How Retirement Saving Programs Increase Saving." The Journal of Economic Perspectives, 10(4), 91-112

44. Poterba, James M., Steven F. Venti, and David A. Wise. 1997. "The Effects of Special Saving Programs on Saving and Wealth." in M. Hurd and N. Yashiro (ed.), The Economic Effects of Aging in the United States and Japan. University of Chicago Press.

45. Poterba, James M., Steven F. Venti, and David A. Wise. 2001. "The Transition to Personal Accounts and Increasing Retirement Wealth: Macro and Micro Evidence." NBER Working Paper No. W8610.

46. Pries, Michael. 2005. "Social Security Reform and Intertemporal Smoothing." Journal of Economic Dynamics and Control, forthcoming.

47. Ruhm, Christopher J. 1990. "Bridge Jobs and Partial Retirement." Journal of Labor Economics, Vol. 8, No. 4, 482-501.

48. Rust, John, and Christopher Phelan. 1997. "How Social Security and Medicare Affect Retirement Behavior in a World of Incomplete Markets." Econometrica, $65-4,781-831$.

49. Rust, John, 2005. "Impact of Retiree Health Plans on Faculty Retirement Decisions," in Robert Clark and Jennifer Ma (editors) Recruitment, Retention and Retirement: The Three R's of Higher Education in the 21st Century, Edward Elgar Northhampton, Massachusetts pp. 135-169.

50. Samwick, Andrew. 1998. "New Evidence on Pensions, Social Security and the Timing of Retirement." Journal of Public Economics, 70(2): 207-236.

51. Scholz, John Karl, Ananth Seshadri, and Surachai Khitatrakun. 2003. "Are Americans Saving 'Optimally' for Retirement?" NBER Working Paper No. W10260.

52. Shoven, John and Clemens Sialm. 2003. "Asset Allocation in Tax-Deferred and Conventional Savings Accounts." Journal of Public Economics, 88, 23-38.

53. Storesletten, Kjetil, Chris I. Telmer and Amir Yaron. 1999. "The Risk-Sharing Implications of Alternative Social Security Arrangement." Carnegie-Rochester Conference Series on Public Policy, Volume 50 , June, Pages 213-259 
54. Van der Klaauw, Wilbert, and Kenneth I. Wolpin, 2005. "Social Security and the Retirement and Savings Behavior of Low Income Households." PIER Working Paper 05-020.

55. Venti, S. F. and D. A. Wise. 1986. "Tax-deferred Accounts, Constrained Choice and Estimation of Individual Saving." Review of Economic Studies, 53(4), 579601.

56. Venti, S. F. and D. A. Wise. 1987. "IRAs and Saving," in Martin Feldstein, ed., The Effects of Taxation on Capital Accumulation. University of Chicago Press, 7-48.

57. Venti, S. F. and D. A. Wise. 1990. "Have IRAs Increased U.S. Saving? Evidence from Consumer Expenditure Surveys." Quarterly Journal of Economics, 105(3), 661-98.

58. Venti, S. F. and D. A. Wise. 1991. "The Saving Effect of Tax-Deferred Retirement Accounts: Evidence from SIPP." In Bernheim, B. Douglas, and John B. Shoven, eds., National Saving and Economic Performance. University of Chicago Press, pp. 103-30.

59. Venti, S. F. and D. A. Wise. 1992. "Government Policy and Personal Retirement Saving." In Poterba, James M., eds., Tax Policy and the Economy. Vol. 6, MIT Press, pp. 1-41.

60. Venti, S. F. and D. A. Wise. 1995. "Individual Response to a Retirement Saving Program: Results from U.S. Panel Data." Riocerche-Economiche, 49(3), 235-54. 